Acta medico-historica Rigensia (2019) XII: 22-66

doi:10.25143/amhr.2019.XII.02

Vladimirs Kuzņecovs, Marina Loseviča

\title{
Psihiatrijas attīstība Krievijas impērijas Vidzemes, Kurzemes un Igaunijas guberņās 19. gadsimta beigās: Emīla Krēpelīna darbība (1886-1891) ${ }^{1}$
}

\section{Anotācija}

Rakstā ir aplūkota situācija psihiatrijā Krievijas impērijas Vidzemes, Kurzemes un Igaunijas guberņās laikā, kad slavenais psihiatrs Emīls Krēpelīns (Emil Kraepelin, 1856-1926) strādāja par Vidzemes guberņas ārstu, vadot Dorpatas (Jurjevas, mūsdienu Tartu) Universitātes Nervu un psihisko slimību klīniku. Lai ilustrētu E. Krēpelīna ieguldījumu reǵiona nozares attīstībā, rakstā ir ietverts arī viņa parakstīts nosūtījums slimniekam uz Aleksandra Augstumu slimnīcu Rīgā un no Dorpatas Nervu un psihisko slimību klīnikas pārvestas pacientes dokumentācija.

Atslēgvārdi: Emīls Krēpelīns, Dorpatas Universitāte, psihiatrija, Krievijas impērijas Baltijas provinces, Aleksandra Augstumu slimnīca, 19. gadsimta beigas, sociālā aprūpe, speciālā pedagoǵija.

\section{Ievads}

Astoņpadsmitajā gadsimtā pilsētas vēl nebija lielas un psihiski slimie maz traucēja iedzīvotājiem. Viṇi nonāca klosteros, cietumos, patversmēs, tika turēti mājās un cieta no piederīgo vardarbības vai arī kḷuva par klaidoṇiem. Savukārt 19. gadsimtā Eiropas iedzīvotāju vidējā dzīvildze pieauga par

1 Raksta autori pateicas Krievijas Federācijas Prezidenta bibliotēkas Starptautisko sakaru nodal̦as galvenajai menedžerei Valērijai Vital̦jevnai Jeresovai par attālināto piekḷuvi arhīva materiālu elektroniskajām kopijām, kā arī psihiatram Aleksandram Losevičam par atbalstu raksta tapšanā. 
15 gadiem un iedz̄̄votāju skaits gandrīz dubultojās. ${ }^{2}$ Sabiedrība prasīja gan atbrīvot to no agresīviem slimniekiem, gan aprūpēt bezpalīdzīgos. Psihiski slimo aprūpe kḷuva par tautas morālā un intelektuālā līmeņa rādītāju.

Vidzemes, Kurzemes un Igaunijas guberņās jau kopš to izveidošanas sākuma bija sarežginita tiesiskā sistēma: bija vairāki tiesiskuma avoti, dažādām sabiedrības kārtām (zemniekiem, muižniekiem un pilsētniekiem) bija atsevišksa tiesiskā sistēma. ${ }^{3}$ Krievijas imperatora Aleksandra III (1881-1894) valdīšanas laikā guberņas galīgi zaudēja savu īpašo statusu. Ģermanizāciju nomainīja rusifikācija. Krievu valoda tika uzspiesta un kḷuva par dominējošo. Izglītības iestādes pārsvarā tika pārorganizētas uz mācībām krievu valodā. Deviṇpadsmitā gadsimta otrajā pusē Krievijā un arī Vidzemes, Kurzemes un Igaunijas guberņās intensīvi attīstījās kapitālisms; sevišķi intensīvi rūpniecība attīstījās Rīgā. Darba migrācijas dēl pilsētās strauji pieauga krievu īpatsvars. 1877. gadā Vidzemes, Kurzemes un Igaunijas guberņās tika ieviesta Krievijas pilsētu tiesību sistēma.

Deviņpadsmitā gadsimta otrajā pusē kḷuva skaidrs, ka psihiski slimo un aprūpējamo skaits ir daudz lielāks, nekā iepriekš bija pieņemts uzskatīt. Slimo skaits (ar nelielu sieviešu pārsvaru) pieauga pēc katra epidemioloǵiskā pētījuma. Anglijā un Velsā 1860. gadā bija viens slimnieks uz 524 iedzīvotājiem, 1870. gadā - jau 1 : 450, 1877. gadā - 1 : 366; 1891. gada sākumā - $1: 200$ (ieskaitot aprūpējamos, kuri dzīvoja ǵimenēs). Šlēsvigas-Holšteinas apvidū (mūsdienu Vācijas Republikā) 1803. gadā uz 10000 iedzīvotāju bija 11 psihiski slimo (jeb 1 : 909), 1840. gadā - 28, bet 1880. gadā - 34 slimnieki. ${ }^{4}$ Savukārt Vidzemes guberņā 1840. gadā bija viens slimnieks uz 670 iedzīvotājiem. Tas bija lielākais rādītājs visā Krievijas impērijā (kur vidēji bija $1: 2700$ ) - tas nepārprotami norādīja, ka tur tiek labāk ievākti statistikas dati par psihiskajiem traucējumiem. Kurzemes guberņā šis rādītājs bija 1 : 2900, Igaunijas guberņā - $1: 1000 .^{5}$ 1880. gadā Igaunijas guberņā bija 48 slimnieki uz 10000 iedzīvotāju,

2 Iukhan Luiga, Prizrenie dushevnobol'nykh v Pribaltiiskom krae. Dissertatsiia na zvanie doktora meditsiny (Iurj'ev, 1904), Istoriya prizrenia dushevnobol'nykh $v$ ostzejskih guberniyah, 12.

3 A. Blagoveshchenskii, Ostrov Ezel', gorod Arensburg i ikh dostoprimechatel'nosti (Sankt-Peterburg: Tip. Imp. Akad. nauk, 1881), 29.

4 Nikolai Popov, "Rol' i znachenie psikhiatrii v sovremennoi nauke i v zhizni," Nevrologicheskii Vestnik 2 (1894): 22.

5 Iukhan Luiga, Prizrenie dushevnobol'nykh v Pribaltiiskom krae. Dissertatsiia na zvanie doktora meditsiny, Statistika dushevnobol'nykh v Pribaltiiskom krae (Iurj'ev, 1904), 1. 
Vidzemes guberņā - 41,5: 10 000;6 1884. gadā Kurzemes guberṇā - $1: 400$ jeb 25 : 10000.7 Tika uzskatīts, ka apmēram trešdaļai slimnieku ir nepieciešama aprūpe psihiatriskā iestādē. ${ }^{8}$

Pirmo reizi metodolog̣iski nevainojama psihiski slimo skaitīšana notika 1871. gadā Šveicē, Bernes kantonā, kur tika konstatēts neliels sieviešu pārsvars (51,96 \% sieviešu pret 48,04 \% vīriešu) ${ }^{9}$

Deviṇpadsmitajā gadsimtā Eiropā mainījās gan sociālā iekārta, gan dzīves ritms un psihiatri ieraudzīja bēdīgu realitāti: arvien pieaugošu urbanizāciju, pauperisma izraisītu slimību izplatību, ${ }^{10}$ "tautas deǵenerāciju”, "deǵenerātu” dezadaptāciju: alkoholismu, narkomāniju, pieaugošu noziedzību un jaunus noziegumu veidus. Turklāt represīvās sankcijas bija bezspēcīgas - piemēram, Anglijā kādu laiku pat par sīku zādzību bija paredzēts nāvessods un zādzības turpinājās tajā pašā laukumā, kur realizēja nāvessodus. ${ }^{11}$ Pat smaga soda perspektīva nespēja atturēt izbadējušos nabagos no noziegumiem; tā laika situāciju labi ilustrē Viktors Igo romānā "Nožēlojamie" (1862). Turpinoties zemnieku pauperizācijai un proletarizācijai, nabadzīgo skaits pieauga - izputinātie zemnieki, sevišķi neražas gados, meklēja pel̦nas iespēju pilsētās, bieži vien cieta tur fiasko un papildināja deklasētās iedzīvotāju šķiras slāni.

Šajā laikā psihiatru uzdevums bija ne vien pārveidot vājprātīgo namus par slimnīcām, atbrīvojoties no penitenciārās un aprūpes funkcijas, bet ar̄̄ izglītot sabiedrību, garīdzniekus, juristus un filozofus par psihisko traucējumu pazīmēm, to atpazī̌sanu (slimo atšksiršanu, piemēram, no klaidoņiem un sliņķiem) un informēt par pienācīgu izturēšanos pret psihiski slimajiem. Šñ psihiatriski izglītojošā darba mērķis bija piesaistīt slimnīcām pēc iespējas vairāk akūti saslimušo, kuriem varētu efektīvi palīdzēt.

6 Iukhan Luiga, Prizrenie dushevnobol'nykh v Pribaltiiskom krae. Dissertatsiia na zvanie doktora meditsiny, Statistika dushevnobol'nykh v Pribaltiiskom krae (Iurj'ev, 1904), 69.

7 Ibid., 97.

8 Ibid., 86.

9 Fedor Naumov, "Organizatsiia psikhiatricheskoi pomoshchi i psikhoprofilaktika", in S. Ia. Svistun, gl. red., Sankt-Peterburgskaia psikhiatricheskaia bol'nitsa sv. Nikolaia Chudotvortsa. K 140-letiiu. Tom 2. Antologiia (Sankt-Peterburg: Kosta, 2012), 691807, https://www.klex.ru/oiw, 715-716.

10 Vārds pauper (latīṇu valodā - "trūcīgs, nabadzīgs") kḷuva par nosaukumu veselam tautas slānim - to apliecina M. Tvena romāns "Princis un ubaga zēns" jeb "The Prince and The Pauper" (1881).

11 Uchenie o prestupnosti i merakh bor'by s neiu. St. Peterburg: Shipovnik, 1912. 
Krievijā vājprātīgo nami kopā ar vispārējā profila slimnīcu, nabagmāju, darba un pārmācības namu, venerisko slimnīcu atradās t. s. Dievam tīkamo iestāžu, kas bija Iekšlietu ministrijas pakḷautībā, sastāvā. Atkarībā no veselības stāvokḷa psihiski slimie tika ievietoti vājprātīgo namā, darba namā vai nabagmājā. Vājprātīgo namā atradās tikai visakūtākie slimnieki, kuri rīkojās galēji nesaprātīgi. Stāvoklim stabilizējoties, tie tika pārvesti uz darba namu (ne tikai tāpēc, ka vājprātīgo namos trūka vietas, bet arī lai varētu atmaksāt savus uzturēšanas izdevumus), bet slimības vai noturīga darbspēju zuduma gadījumā viņus pārveda uz slimnīcu vai nabagmāju. ${ }^{12}$

Deviņpadsmitā gadsimta vidū un otrajā pusē izkristalizējās vairākas psihisko traucējumu likumsakarības: akūti slimnieki atvesel̦ojas dažu nedēḷu (maksimums - mēnešu) laikā, savukārt hroniski slimais iestādē pavada apmēram četrus gadus. Vislabāk (bieži vien gandrīz piln̄̄bā) pacienti atveseļojas no akūtiem, pēkšņiem psihiskiem traucējumiem ar izteiktu psihomotoro uzbudinājumu un garastāvokḷa izmaiņām. Ārstēšanas rezultāts bija labāks sievietēm un zemnieku kārtas pārstāvjiem. ${ }^{13}$ Bija piefiksēta milzīgā vides nozīme - pārpildīti stacionāri un saskarsme ar hroniski slimajiem nel̦auj atlabt nesen saslimušajiem, turpretī mierīga gaisotne, sakārtota vide, produktīvs darbs atbilstoši slimnieka spēkiem un dotībām (t. s. darba terapija) ${ }^{14}$ rada uzlabojumu pat ievērojama psihes defekta gadījumā. Hroniskam slimniekam izredzes uz atveselošanos samazinās ar katru gadu. ${ }^{15}$ Psihohronisko pacientu, īpaši vīriešu, pieplūdums stacionārā drīz vien slimnīcu pārvērš par dārgu nabagmāju, paralizējot ārstniecisko darbu. ${ }^{16}$

12 Visumā šī sistēma atbilst mūsdienu psihiatriskās rehabilitācijas stratēgijai - rehabilitācijas pasākumi (tostarp darba terapija) jāuzsāk iespējami agrīni, negaidot simptomu pilnīgu redukciju.

13 To, ka zemnieku kārtas pārstāvji atvesel̦ojās ātrāk un labāk, varētu skaidrot ar viṇu grūtajiem dzīves apstākḷiem, nabadzīgu uzturu, regulāru smagu fizisku darbu. Šos faktorus novēršot, viṇu veselība bieži vien ātri uzlabojās, turpretī bagātnieku kārtas pārstāvji ārstēšanos slimnīcā parasti panesa smagi.

14 Pacienti no vājprātīgo nodaḷām tika nodarbināti arī agrāk, taču tikai tolaik tam tika piešķirta terapeitiska nozīme, nodrošinot ar̄̄ šì darba regularitāti.

15 Jau franču psihiatrs Eskirols (Jean-Étienne Dominique Esquirol, 1772-1840) pierādīja, ka pēc trīs gadu slimošanas atvesel̦ojas ne vairāk par 1/30 slimnieku, pēc otrā slimības gada iespējas strauji sarūk un, ja gada laikā nav bijusi nozīmīga uzlabošanās, uz atveseḷošanos nevar cerēt.

16 Liia Iangulova, "Doma umalishennykh v Rossii: filantropicheskaia psikhiatriia i politika gendera,” Zhurnal Issledovanii Sotsial'noi Politiki 11, no. 3 (2013): 377-390. 
Psihiatriskajā praksē tika ieviesta mierīgo nodal̦a (jeb no restraint, open door sistēma). Zināšanas par prognozi l̦āva ieviest slimnieku šķirošanu ${ }^{17}$ un ārstniecības pasākumus koncentrēt uz potenciāli izārstējamiem pacientiem, savukārt akūti slimajiem palika slimnīcas, kur izmantoja modernas ārstēšanas metodes. Hroniski ("nedziedināmi”) slimajiem, kuri spēja strādāt, - ǵimenes aprūpe, agrārās kolonijas, ${ }^{18}$ bet pārējiem (“nespējniekiem”) - patversmes jeb nabagmājas (almshouses; bogadel'ni). Hronologíski tas sakrita ar sociālās palīdzības un aprūpes attīstības progresu. Līdz ar Apgaismības laikmetu un Lielās franču revolūcijas humānisma ideju ieviešanu Rietumeiropas valstīs individuālās un sabiedriskās labdarības iniciatīvas beidzot tika apvienotas ar valsts pūlēm nabadzīgo un slimo aprūpē, izveidojot sociālās palīizzības tīklu.

\section{Aleksandra Augstumi - koridortipa slimnīca laikmeta kontekstā}

Jau 19. gadsimta pirmajā pusē kḷuva skaidrs, ka psihiatrisko iestāžu plānojumam un iekārtojumam ir liela nozīme. Krievijas psihiatrs Pjotrs Butkovskis ( $P$ 'jotr Aleksandrovich Butkovskyi, 1801-1844) pirmajā krievu psihiatrijas mācību grāmatā aprakstīja vienstāva trakonamu prioritātes pār vairākstāvu iestādēm. Viņš rakstīja, ka vairākstāvu namos ir grūtības rūpīgi uzraudzīt pacientus, bet, viņus atstājot izolācijāa dažos Anglijas un Francijas trakonamos bija liels suicīdu skaits. Tādēḷ, "ierīkojot trakonamu vairākos stāvos, uzraudzība kḷūst par grūtu un bīstamu darbu”. ${ }^{19}$ Butkovskis norādīja, ka uzraugus nevajadzētu algot no viszemākajiem

17 Slimniekus iedalīja arī pēc pamatpazīmēm - epileptiķi, lunātiķi, melanholiķi, trakojošie (beshennye). Sk.: Liia Iangulova, "Doma umalishennykh v Rossii: filantropicheskaia psikhiatriia i politika gendera," Zhurnal Issledovanii Sotsial'noi Politiki 11, no. 3 (2013): 377-390.

18 Gan zemstes, gan prikazu psihiatriskās iestādes Krievijā bija pārpildītas. Tādēl tika piedāvāts hroniskus slimniekus nodot aprūpei (zemnieku) ǵimenēm, kā to darīja Eiropas valstīs, vai arī ierīkot agrārās kolonijas. PSRS teritorijā ǵimenes aprūpe pastāvēja līdz 20. gadsimta 70. gadiem, un tā joprojām pastāv vairākās Eiropas valstīs. Sk.: M. Nekrasov, "Patronage familial - odna is form organizatsii psikhiatricheskoi pomoshchi v dorevoliutsionnoi Rossii," Rossiiskii Psikhiatricheskii Zhurnal 6 (2015): 68-74.

19 Petr Butkovskii, Dushevnye bolezni, izlozhennye soobrazno nachalam nyneshnego ucheniia psikhiatrii v obshchem i chastnom, teoreticheskom i prakticheskom soderzhanii (Sankt-Peterburg: Tipografiia I. Glazunova, 1834), 1: 99. 
sabiedrības slāṇiem, ka viṇu ārējam izskatam jābūt "ne pārāk pretīgam”, jāgeērbjas tīri un kārtīgi un nevajadzētu līdzi nēsāt nūjas vai citus aizsardzības līdzekḷus. Viņš rakstīja, ka, piemēram, Bisetrā (pie Parīzes) un Salpetrjēra (Parīzē) slimnīcā lielākā daḷa uzraugu un uzraudžu ir bijušie slimnieki - jo viņi ir žēlsirdīgāki un slimnieki tiem vairāk uzticas. ${ }^{20}$ Iespējams, tādēḷ psihiatriem radās izteiciens "pacienti ir slimi, bet personāls - robežstāvoklī’".

Vakareiropā un Krievijā vecā tipa psihiatriskās iestādes bija t. s. kazarmu tipa jeb koridortipa (Corridorsystem) celtnes. Lai taupītu platību un neveidotu atsevišksas telpas slimnieku uzturēšanai pa dienu, kā pamatu garam un šauram korpusam izmantoja centrālo koridoru un abās tā pusēs izvietoja palātas, istabas utt. Galvenajam korpusam bija 3-4 stāvi, uz augšējo stāvu logiem bija restes vai sieti (logu rūtīs bija kuğu stikls, taču arī to uzbudinātie slimnieki regulāri izsita). Korpusi savā starpā bija savienoti ar gaiteņiem. Šis iestāžu veids izrādījās nehigiēnisks un neērts saimnieciskajā un administratīvajā ziṇā. Ja slimnieku skaits bija lielāks, vajadzēja gādāt papildu saimnieciskās ēkas. Centrālais koridors bija garš un smacīgs. Nebija iespējams dažādu grupu slimniekiem piedāvāt atsevišķas telpas, un pa dienu slimniekiem bija jāuzturas vienā koridorā, tādēl raisījās fiziskas sadursmes un radās vajadzība tās novērst ar dažādiem ierobežojošiem pasākumiem. Iestādes bija tumšas, tās bija grūti uzturēt tīras.

Iegarenā korpusa fasāde aizn̦ēma daudz vietas, un, ja pie slimnīcas bija pagalms pastaigām, tad tā takas neizbēgami stiepās gar korpusu. Ja bija vēl citi korpusi, tad veidojās it kā slēgta telpa, ko varēja labi caurskatīt no visām nodaļām. Tā nesniedza mieru klusiem slimniekiem, kas meklēja vientulību, savukārt nemierīgos slimniekus satrauca vēl vairāk, jo vin̄i redzēja pretējā dzimuma slimniekus. Nebija iespējams nodrošināt klusumu un mieru, efektīvi nodalīt sieviešu un vīriešu istabas, arī akūtus infekciozus slimniekus nebija iespējams izolēt. Sieviešu un vīriešu galos bija nepieciešams vismaz pa vienam izolatoram. Tādā iekārtojumā bija grūti ieviest t. s. mierīgo nodaļas jeb open-door sistēmu. Bija novērots, ka psihiski slimajiem ir nosliece uz infekcijas slimībām (tīfu, rozi, plaušu tuberkulozi), kas lielajās un pārpildītajās slimnīcās ieguva endēmisku un epidēmisku raksturu. Šādu slimnīcu izmaksas bija milzịgas.

20 Petr Butkovskii, Dushevnye bolezni, izlozhennye soobrazno nachalam nyneshnego ucheniia psikhiatrii v obshchem i chastnom, teoreticheskom i prakticheskom soderzhanii (Sankt-Peterburg: Tipografiia I. Glazunova, 1834), 108-109. 


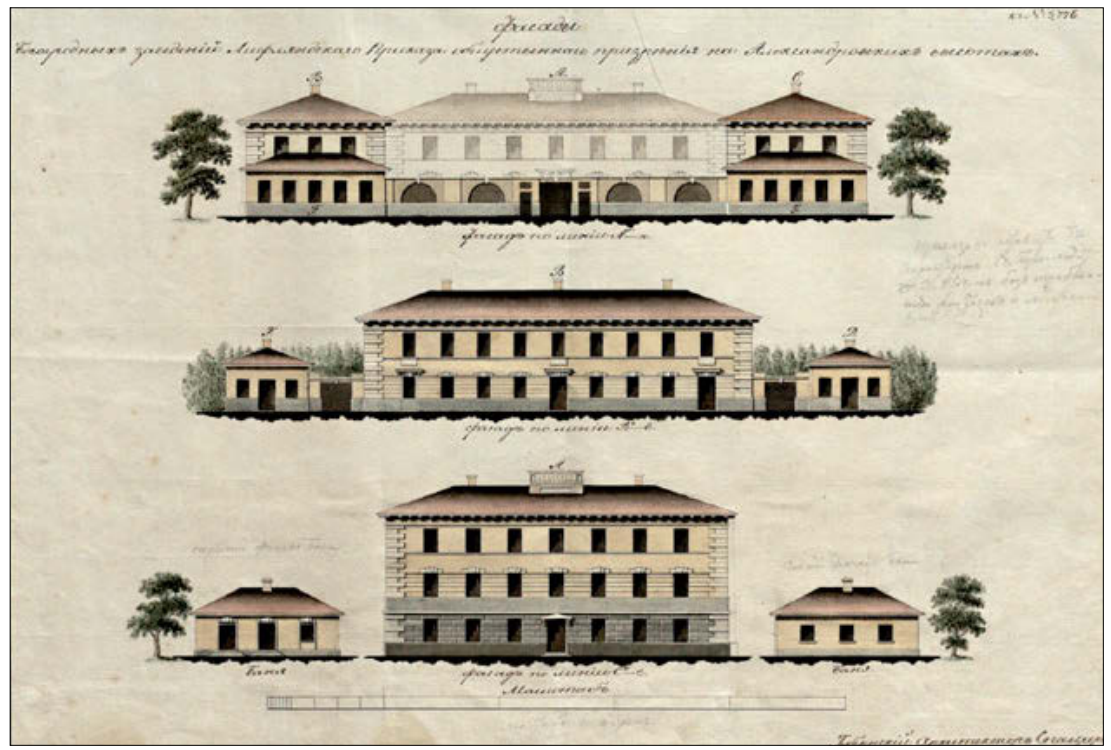

Vidzemes guberņas Sabiedriskās aizgādības kolēgijas Dievam tīkamo iestāžu fasādes no dažādiem rakursiem Aleksandra Augstumos, ap 1825.-1827. gadu (avots: Krievijas Valsts vēstures arhīvs, 1293. fonds, 168. apraksts, 37. lieta.

Identifikators e404b9d1-b817-4597-a962-4ab7ac249497.

Iegūts no Krievijas Federācijas Prezidenta bibliotēkas; prlib.ru)

Apakšêjā attēlā galvenās ēkas abās pusēs atainota pirts - tās priekšêjā un mugurējā fasāde (skaidrojums rakstīts ar zīmuli). Parakstīja guberņas arhitekts Špacīrs (J. A. Spazier, dz. ap 1790-miris pēc 1870; zināms, ka 1825.-1827. gadā Špacīrs aktīvi piedalījies Aleksandra Augstumu iestāžu paplašināšanā).

Tas viss liecināja, ka koridortipa psihiatriskās slimnīcas ir novecojušas, vairs neatbilda laikmeta prasībām, tādēl tās nomainīja t. s. paviljona tipa (Pavillonsystem, ar sānu koridoru) celtnes.

Taču Vidzemes guberņā 1824. gadā izveidotais Aleksandra Augstumu vājprātīgo nams bija koridortipa celtne, kurai piemita dažādi plānošanas un būvniecības trūkumi. Piemēram, vīriešu nodaḷā pirmais stāvs bija zemes līmenī, savukārt sieviešu nodaḷā - zemāk par zemes līmeni. Uzbudināto slimnieku izolācijai - tieši šie slimnieki labi veseḷojās un kḷuva par ārstēšanas mērķi - katrā nodaḷā bija tikai pa vienai istabai (kambarītis, karceris, kamorka, Schwarzkammer), kas atradās pie atejas. Nebija ne telpu, kur slimniekiem atrasties pa dienu, ne meistardarbnīcu un 
noliktavu, ne vannas istabu un atsevišķu istabu smagi slimajiem. Netika domāts par to, ka atsevišksi vajadzētu izvietot psihiski slimos, veneriski slimos un arestantus. Invalīdi un arestanti tika nodarbināti psihiski slimo aprūpē. Pastāvīgs ārsts Aleksandra Augstumos darbā tika pieņemts tikai 1845. gadā. ${ }^{21}$

Populācijas pētījumos tika pierādīts, ka psihisko traucējumu prevalence ir nedaudz lielāka sieviešu vidū, tādēl rietumu psihiatru prātos nostiprinājās doma, ka sievietēm biežāk rodas psihiski traucējumi. To pastiprināja idejas par reproduktīvās funkcijas un hormonālo svārstību ietekmi uz psihozes rašanos. Turpretim Krievijas vājprātīgo namos prevalēja vīrieši. Izcilais psihiatrs Pāvels Jakobi 1900. gadā rakstīja, ka, pēc viņa domām, sieviešu vidū psihisko traucējumu incidence ir lielāka, bet viņas ātrāk atvesel̦ojas. ${ }^{22}$ Viņš norādīja, ka vīriešu psihožu gadījumos pacienti biežāk ir smagi slimi un nedziedināmi. Vīriešu pārsvaru Krievijas vājprātīgo iestādēs tā laika pētnieki skaidroja ar šo iestāžu penitenciāro raksturu. ${ }^{23}$ Šo izskaidrojumu apgāž Kurzemes guberņas prikaza slimnīcas vājprātīgo nodaḷas statistika (vīriešu ir vairāk, bet iestādē nav penitenciāro klientu).

Jakobi pierādīja - jo vairāk starp slimniekiem vīriešu, jo ātrāk slimnīca pārpildās un pārvēršas par nabagmāju. Zemāko šksiru sievietēm psihiski traucējumi ir mazāk uzkrītoši, jo tie maz satrauc ǵimeni - "psihoze netiek pamanīta, bet pat tad, ja ir pamanīta, tiek izskaidrota ar parastu sieviešu dullumu; dullie sievišķi (durenie baby) zemnieku ǵimenē bija tikpat izplatīta parādība kā dāmu kaprīzes - aristokrātu ǵimenē". ${ }^{24}$ Ar sievietēm tikt galā bija vieglāk, taču zemnieki piekrita atteikties no darbarokām tikai tad, kad stāvoklis vairs nebija ciešams. Tādēḷ sievietes - atšķirīibā no vīriešiem - psihiatriskajās iestādēs nonāca novēloti un ar intensīvākiem simptomiem (vismaz tā notika ar zemāko šksiru pārstāvēm). Šādi Jakobi mēgināja skaidrot arī tā laika pieņēmumu, ka sieviešu psihozēm ir intensīvāka forma nekā vīriešiem. Mūsdienās ir skaidrs, ka sieviešu psihozēm ir izteiktāka afektīva simptomātika, tām ir raksturīga epizodiska norise,

21 Iukhan Luiga, Prizrenie dushevnobol'nykh v Pribaltiiskom krae, Istoriya prizrenia dushevnobol'nykh v ostzejskih guberniyah, 47.

22 Liia Iangulova, "Doma umalishennykh v Rossii: filantropicheskaia psikhiatriia i politika gendera,” Zhurnal Issledovanii Sotsial'noi Politiki 11, no. 3 (2013): 377-390, 387.

23 Ibid., 380.

24 Pavel Iakobi, Osnovy administrativnoi psikhiatrii (Orel, 1900), 358. 
savukārt vīriešu psihozēm biežāk ir tendence uz nepārtrauktu, tādēḷ afektīvi mazāk bagātu klīnisko ainu. Arī mūsdienās psihisko traucējumu izplatība starp dzimumiem atšķiras - piemēram, Eiropā trauksme, depresija, bipolaritāte ir vairāk tipiskas sievietēm, savukārt alkohola un atkarības vielu (narkotiku) lietošana ir divreiz biežāka vīriešiem. ${ }^{25}$

Deviṇpadsmitajā gadsimtā psihiatriskās iestādes tika strauji pārpildītas. Agrākais psihiatru uzdevums - piesaistīt slimnīcām pēc iespējas vairāk slimnieku (ar cerību akūtos izārstēt, savukārt hroniskos pasargāt no vardarbības un aprūpēt) - tika nomainīts pret deinstitucionalizāciju.

\section{Aleksandra Augstumi ārpus deinstitucionalizācijas}

Tā kā Krievijā prikazu vājprātīgo namiem (jeb Sabiedriskās aizgādības kolēgiju Dievam tīkamo iestāžu vājprātīgo nodaḷām) bija bēdīga slava, bet vajadzība pēc psihiatriskās palīdzības arvien pieauga, tika nolemts uzsākt jauna tipa psihiatrisko slimnīcu celtniecību, kurām vajadzēja atbilst tā laika medicīnas standartiem. Uz prikazu slimnīcām bija paredzēts sūtīt nedziedināmus slimniekus.

Tā sāka būvēt zemstes slimnīcas - tās plānoja un būvēja, vadoties no terapeitiska entuziasma (t. i., vēlmes aktīvi darboties, izmantot dažādas metodes pacienta ārstēšanā, lai panāktu ievērojamu uzlabošanos), cerot, ka iedzīvotāji laikus ievietos slimnīcā savus piederīgos vājprāta gadījumā. Slimnīcas būvēja, ievērojot higiēnas normas - gaišas un plašas, pēc iespējas novēršot slimnieku ierobežošanu. Tika ieviesta darba terapija: darbn̄̄cās un dabā (dārzā, mežā, uz lauka). Darbā tika pieņemti skoloti psihiatri. Rezultātā pieauga izveseļojušos slimnieku skaits un samazinājās mirstība. Slimnieku populācijas pieaugums bija $5 \%$ gadā. ${ }^{26}$ Lai paātrinātu palīdzības saņemšanu, zemstu psihiatriskajās slimnīcās pakāpeniski pārgāja uz ārstēšanu bez maksas.

Vidēji lielajās zemstu psihiatriskajās slimnīcās (400-600 gultu) izmaksas uz katru slimnieku bija zemākas nekā lielajās (600-800 gultu). Vislētākā zemstu psihiatriskā slimnīca bija Saratovas slimnīca, kur

25 OECD/EU (2018), Health at a Glance: Europe 2018: State of Health in the EU Cycle, OECD Publishing, Paris, https://doi.org/10.1787/health_glance_eur-2018-en.

26 Fedor Naumov, "Organizatsiia psikhiatricheskoi pomoshchi i psikhoprofilaktika", 719. 
slimnieka vidējās uzturēšanas izmaksas no 230 rubḷiem 1884. gadā samazinājās līdz 159 rubl̦iem 1893. gadā. ${ }^{27}$

Arī mirstība lielajās slimnīcās bija augstāka. Bija pierādīts - jo lielāka slimnīca, jo tā mazāk uzṇem akūtos slimniekus un ātri kḷūst par dārgu un bezjēèzīgu psihiatrisku nabagmāju, patversmi “psihohroniķiem”. Piemēram, prikazu "baisajās" psihiatriskajās nodaḷās mirstība bija 20-30 \%. Divdesmitā gadsimta sākumā tā samazinājās līdz pat pieciem procentiem. ${ }^{28}$

Savukārt tajās Krievijas guberṇās, kur nepastāvēja zemstes, psihiatrisko slimnīcu ierīkojums palika iepriekšējā galēji zemajā līmen̄̄, jo slimnieku skaits arvien pieauga. Tāpēc bija nolemts būvēt apgabalu slimnīcas: Tvorkās pie Varšavas, pie Viḷnas, Vinnicā, Maskavā un Tomskā.

Kā zināms, Baltijas guberņās zemstes netika ieviestas, bet lēmums būvēt lielu apgabala slimnīcu visu triju guberņu vajadzībām dažādu (finansiālu un lingvistisku šksēršşu, vietējās muižniecības pretestības) iemeslu dēḷ netika īstenots. ${ }^{29}$

Aleksandra Augstumu psihiatriskajai nodal̦ai Krievijas impērijā bija slikta slava - tā (līdzās Tveras un Astrahaņas psihiatriskajām iestādēm) bija viena no trīs slimnīcām, kas atradās vissliktākajā stāvoklī. Domājams, ka izārstēto bija maz (slimnieki gaidīja garā rindā un nonāca iestādē tikai tad, kad atbrīvojās vieta un cerību uz izārstēšanos gandrīz nebija), tāpēc uzraksts kā uz elles vārtiem Dantes Aligjēri darbā "Dievišksā komēdija" “Tu, kas šeit ieej, atstāj cerīb’ ārā” - bija tai piemērots sauklis. ${ }^{30}$ Aleksandra Augstumu vājprātīgo nams pastāvīgi funkcionēja ar pārslodzi un nelielu vīriešu slimnieku pārsvaru, piemēram, 1879. gadā Aleksandra Augstumu iestādēs uz trim ārstiem bija 192 slimnieki. No tiem 90 vājprātīgi, pārējie sifilisa slimnieki un nabagmājas / nespējnieku mājas iemītnieki (de iure nabagmāja bija likvidēta, bet faktiski Aleksandra Augstumos turpināja pastāvēt reducētā veidā (visticamāk, tagadējā Patversmes ielā). 1893. gada sākumā vājprātīgo nodaḷā atradās 77 vīrieši un 70 sieviešu. Gada laikā

27 T. Iudin, Ocherki istorii otechestvennoi psikhiatrii (Moskva: Medgiz, 1951), 180, http://www.psychiatry.ru/siteconst/userfiles/file/PDF/2806/Ocherki2.pdf

28 Fedor Naumov, "Organizatsiia psikhiatricheskoi pomoshchi i psikhoprofilaktika”, 731.

29 Vladimirs Kuzṇecovs un Marina Loseviča, "Baltijas valsts psihiatrisko iestāžu plāni 19. gadsimtā," Latvijas Universitātes raksti, Zinātṇu vēsture un muzejniecība 814 (2016): 43-54.

30 Iukhan Luiga, Prizrenie dushevnobol'nykh v Pribaltiiskom krae, Istoriya prizrenia dushevnobol'nykh v ostzejskih guberniyah, 27 (citējot Dr. med. G. Holtu (Georg Holdt (1829-1881), Aleksandra Augstumu virsārstu un direktoru (1863-1868). 
septiņi vīrieši un astoņas sievietes izrakstîjās, 11 vīrieši un 14 sievietes iestājās, savukārt četri vīrieši un 12 sievietes nomira, aizbēdzis neviens nebija. ${ }^{31}$

Prakse liecināja - psihohronisko pacientu uzraudzībai pietiek ar vienu ārstu uz 100-200 un vairāk slimnieku (dažās Francijas iestādēs bija viens ārsts uz 800-1000 hronisku slimnieku), savukārt ar nesen saslimušo pareizu ārstēšanu tik tikko tika galā viens psihiatrs uz 25-30 slimniekiem. Piemēram, Drēzdenes psihiatriskā slimnīca bija slavena ar remisiju sasniegušo pacientu izcilo procentuālo skaitu. Ar 60-65 akūtiem slimniekiem strādāja četri pieredzējuši psihiatri. Tātad viens ārsts strādāja ar 15 pacientiem. ${ }^{32}$ Ja pacientu skaits bija lielāks, pat visatbildīgākais ārsts nespēja izdarīt neko vairāk par novērošanu un aprūpi, savukārt ārstēšana notika tikai galējas vajadzības un izdevības gadījumā. Kāds no tā laika psihiatriem praktiķiem izteicās, ka psihiatrisko iestāžu pārpild̄̄̌sanai ir tikpat smagas sekas kā dzemdētāju drudzim dzemdību nodaḷā - tā pilnīgi iznīcina slimnīcas dziedinošo efektu, rada tik smagas morālās un higiēniskās sekas, ka pat cerīgs pacients kḷūst par nedziedināmu hronisku slimnieku (lai gan mājas apstākḷlos viṇš varētu atlabt); tāda slimnīca kḷūst par "nedziedināmo fabriku” un garantē "drošu pāreju plānprātībā". ${ }^{33}$

Zemstes medicīnas statistikas dati liecināja, ka korektai psihiatriskās palīdzības īstenošanai katrā guberṇā būtu nepieciešamas trīs slimnīcas. Katras slimnīcas efektīvās "darbības rādiuss" nepārsniedz 50-60km, jo procentuāli visvairāk slimnieku izvesel̦ojas no slimnīcai tuvākām teritorijām (21\%, salīdzinot ar 7,5 \% no attālākām teritorijām), kas varētu būt skaidrojams ar palīdzības sniegšanas operativitāti. Pieredze arī rādīja, ka sākotnēji labi un dārgi iekārtotas psihiatriskās slimnīcas Krievijā pārvērtās par dārgām nabagmājām, jo tās ātri aizpildīja hroniskie slimnieki. Vēl 19. gadsimta 70. gados izcils vācu psihiatrs Vilhelms Grīzingers (Wilhelm Griesinger, 1817-1868) ieteica ierīkot vairākas nelielas psihiatriskās slimnīcas, kas apkalpotu visus akūtos slimniekus. Piemēram, Drēzdenes un tās piepilsētu iedzīvotājus - 600-650 tūkstošus cilvēku - veiksmīgi apkalpoja viena slimnīca ar 60-65 gultām. Vēl viens akūtās psihiatriskās palīdzības

31 Iukhan Luiga, Prizrenie dushevnobol'nykh v Pribaltiiskom krae, Istoriya prizrenia dushevnobol'nykh v ostzejskih guberniyah, 28.

32 Mūsdienās saskaṇā ar konceptuālā ziņojuma "Par veselības aprūpes sistēmas reformu" 1. pielikumā noteikto Latvijā pieaugušo psihiatrijā ir paredzētas 15 gultas / pacienti uz vienu psihiatru. Sk.: Ar Ministru kabineta 2017. gada 7. augusta rīkojumu Nr. 394 apstiprināts Konceptuālais ziṇojums "Par veselības aprūpes sistēmas reformu".

33 Fedor Naumov, "Organizatsiia psikhiatricheskoi pomoshchi i psikhoprofilaktika”, 728. 
veids - atsevišķas nodaļas somatiskajās slimnīcās - pirmo reizi tika veiksmīgi īstenots dažās Skotijas un Londonas grāfistes slimnīcās (reception houses) ${ }^{34}$ Mūsdienās psihiatriskā palīdzība tā tiek realizēta Itālijā, kur psihiatriskās slimnīcas per se ir likvidētas un akūtā palīdzība tiek sniegta somatisko slimnīcu nodaḷās, kur ir ne vairāk par 15 gultām. ${ }^{35}$ Vācijā jau 19. gadsimta beigās bija ap 50 pilsētu, kur bija līdzīgas nelielas dziednīcas, kas novērsa lielo apgabala slimnīcu pārpildīšanu. ${ }^{36}$

Tātad tika pierādīts, ka gultu skaits tikai dal̦ēji liecina par psihiatriskās palīdzības pieejamību, jo nozīmīgāka ir palīdzības decentralizācija un tās pietuvināšana iedzīvotājiem. Īpaši liela nozīme ir nelielo psihiatrisko slimnīcu tīklam, kas apkalpo nelielas teritorijas. Pēc Rietumu psihiatru viedokḷa, optimāls skaits ir 32-35 gultas uz 100000 iedzīvotāju. Ja viena liela slimnīca apkalpo pārāk lielu teritoriju, tas drīz vien pasliktina ārstēšanas kvalitāti, jo slimnīca ātri piepildās ar neārstējamiem, hroniskiem slimniekiem, kas iestādi pārvērš par "neārstējamo fabriku". Liela un dārga psihiatriska slimnīca traucē psihiatriskās palīdzības reorganizācijai, decentralizācijai, optimizācijai un modernizācijai, liedzot iedzīvotājiem saņemt laikmetam atbilstošu palīdzību arī nākotnē. ${ }^{37}$

Arī mūsdienās šì tendence saglabājas - valstīs, kur ir raksturīga ilgstoša psihiatriskā hospitalizācija, lielākā daḷa budžeta aiziet stacionārajai palīdzībai. ${ }^{38}$ Valstīs, kur veiksmīgi notiek stacionāras psihiatriskās palīdzības deinstitucionalizācijas process, hroniski pacienti (zaudējuši iemaņas dzīvot sabiedrībā un bez ǵimeniskām saiknēm) paralizē akūtās psihiatriskās palīdzības sniegšanu, aizņemot akūtiem slimniekiem paredzētās gultas vietas, kamēr pirmreizēji vai nesen saslimušie pacienti netiek stacionēti, iekams viṇu stāvoklis nav nopietni paasinājies un ir parādījušās izteiktas novirzes. ${ }^{39}$

34 Fedor Naumov, "Organizatsiia psikhiatricheskoi pomoshchi i psikhoprofilaktika", 726.

35 Corrado Barbui, Davide Papola and Benedetto Saraceno, "Forty years without mental hospitals in Italy," International Journal of Mental Health Systems 12 (2018), https:// ijmhs.biomedcentral.com/articles/10.1186/s13033-018-0223-1

36 Fedor Naumov, "Organizatsiia psikhiatricheskoi pomoshchi i psikhoprofilaktika", 727.

37 Ibid.

38 I. Gurovich, O. Papsuev i L. Visnevsakaia, "O pokazateliakh statsionarnoi psikhiatricheskoi pomoshchi Evropeiskikh stran v rezultate deinstitutsionalizatsii," Sotsial'naia I Klinicheskaia Psikhiatriia 26, no. 3 (2016): 89, http://mniip-repo.ru/ uploads/1496326766.pdf

39 Tom K. J. Craig, "Shorter hospitalizations at the expense of quality? Experiences of inpatient psychiatry in the post-institutional era," World Psychiatry 15, no. 2 (2016): 91-92, doi:10.1002/wps.20320. 


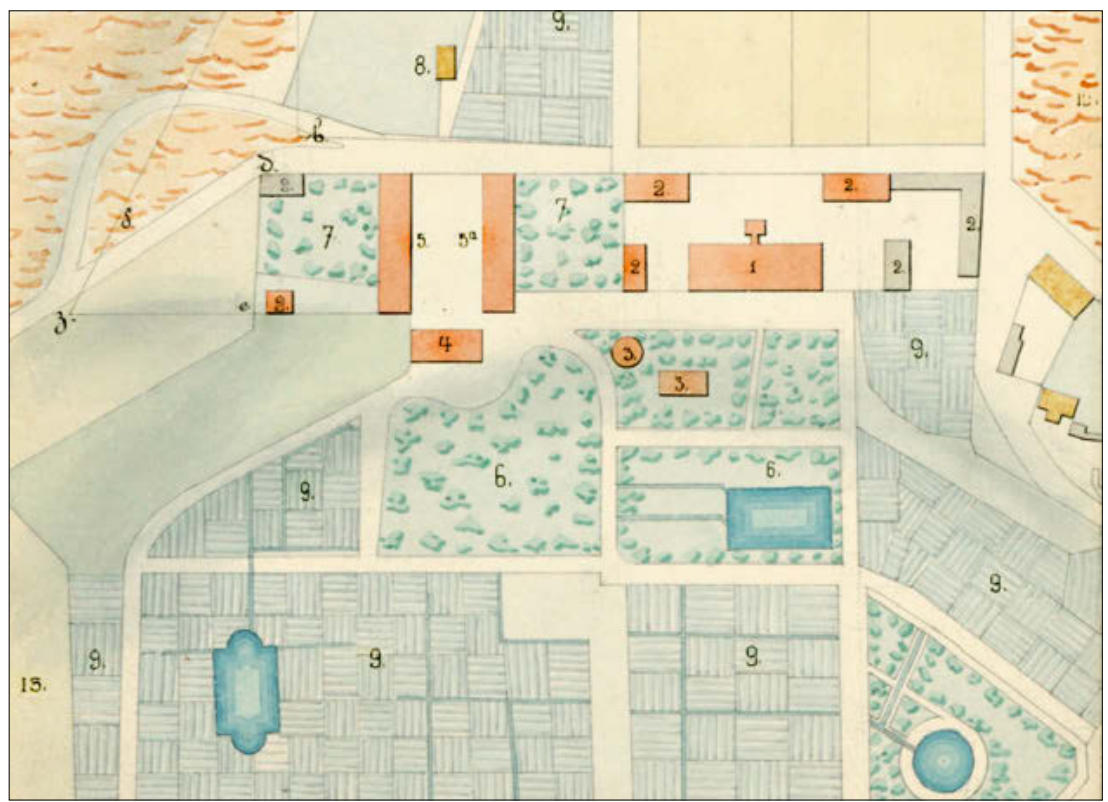

Projekts Rīgas vājprātīgo namam Aleksandra Augstumos, fragments "Situācijas plāns”, 1874. gads (avots: Krievijas Valsts vēstures arhīvs. 1293. fonds, 166. apraksts, 28. lieta, 15. lapa. Identifikators 6dc4c7fc-0861-455f-a632-f1e879b48dfd. Iegūts no Krievijas Federācijas Prezidenta bibliotēkas; prlib.ru)

1 - slimnīca (bijusī darba māja); 2 - palīgdienestu telpas (pirts ar vešūzi un virtuve ar maizes ceptuvi, noliktava u. c.); 3 - gāzes rūpnīca; 4 - turīgo pacientu māja; 5 - vājprātīgo nodaļa sievietēm; $5 \mathrm{a}$ - vājprātīgo nodaḷa vīriešiem; 6 - parki; 7 - dārzi; 8 - baznīca; 9 - sakṇu dārzi

Jauno korpusu ar vairākiem spārniem bija paredzēts būvēt tuvāk dzelzceḷam baznīcas vietā. No attēlā redzamajiem trim dīķiem līdz mūsdienām ir saglabājies tikai viens (taisnstūra formas). 


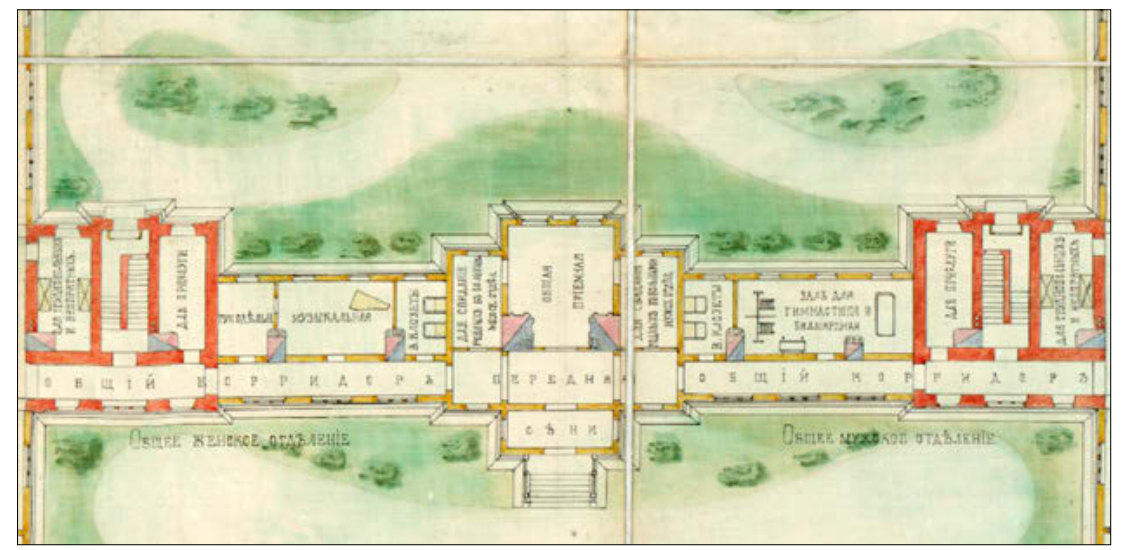

Rīgas Aleksandra Augstumu vājprātīgo nama projekta fragments (iestāde potenciāli izārstējamiem), apakšējā stāva plāna fragmenta kopija, 1876. gads; pievienots komentārs, ka "1874. g. 9. martā psihiatru un tehniķu komisija šo rasējumu atzina par psihiatriski-tehniskā ziṇā apmierinošā stāvoklī esam” (avots: Krievijas Valsts vēstures arhīvs. 1293. fonds, 168. apraksts, 28. lieta. Identifikators 654476f2-28f5-4cb9-b3cf-ce7c8206d0fa. Iegūts no Krievijas Federācijas Prezidenta bibliotēkas; prlib.ru)

Projektu parakstīja profesors I. M. Balinskis (1827-1902, Sanktpēterburgas Medicīnas un ķirurǵijas akadēmijas profesors, Sanktpēterburgas psihiatrijas skolas pamatlicējs), profesors I. Štroms (1823-1887, arhitekts), akadēmiķis M. Mesmahers (Maximilian von Messmacher, 1842-1906). Projekts netika realizēts.

Fragmentā var redzēt uzṇemšanas nodaļu, akūti slimo vīriešu un sieviešu nodalas ar sānu koridoru, kas bija raksturīgs "paviljontipa" slimnīcai. Abās nodaḷās bija paredzētas telpas radinieku apciemošanai, sieviešu nodaḷa - rokdarbu istaba un mūzikas istaba ar klavierēm; vīriešu pusē - vingrošanas zāle un biljards. Pēc raksta autoru domām, tas liecina par cerību iestādē uzṇemt arī pacientus no sabiedrības turīgākajiem slāṇiem, kā arī izpratni par darba terapijas un produktīvas brīvā laika pavadīšanas nozīmi. Vecie Aleksandra Augstumu korpusi (iepriekšējā attēlā - 5 un 5a) bija atvēlēti nedziedināmi slimajiem. VSIA "Rīgas psihiatrijas un narkologijas centrs" sieviešu nodạ̦ās ilgu laiku bija klavieres, bet biljarda vietā vīriešu nodą̧ās bija novuss un citas galda spēles. Pēc projekta autoru ieceres, jaunceltnes augšejā stāvā bija paredzētas arī palātas ekspertējamiem (cilvēkiem, kuri ieradās uz gara un prāta spēju pārbaudi) un ārsta dzīvoklis. 


\section{Baltijas guberņu psihiatriskās \\ palīdzības iestāžu raksturojums}

Kopumā Krievijas impērijas augstāko šķiru iedzīvotāji labāk izvēlējās ārstēties ārzemēs - Francijā vai Vācijas kūrortos Reinas upes krastos. ${ }^{40}$ Līdzịga tendence iezīmējās arī Osmaņu impērijā - 19. gadsimta beigās pārtikušās ğimenes sāka sūtīt savus slimniekus uz Eiropu - Zviedriju, Vāciju vai Austriju - gan labākās ārstēšanas meklējumos, gan pašmāju iestāžu pārpildītības dēḷ. ${ }^{41}$ Deviṇpadsmitā gadsimta beigās un divdesmitā gadsimta sākumā Baltijas guberņu iedz̄ivotājiem nebija lielas izvēles, kur saņemt stacionāro psihiatrisko palīizību.

Vidzemes guberṇā 1904. gadā darbojās vismaz deviņas tādas iestādes. ${ }^{42}$

1. Prikaza slimnīca Aleksandra Augstumos - 1824. gadā Dievam tīkamās iestādes tika pārceltas no Rīgas Citadeles uz piepilsētu; 20. gadsimta sākumā tur bija 138 gultas psihiski slimajiem. ${ }^{43}$ Heinrihs Lērs un Makss Lēvalds 1899. gadā Aleksandra Augstumus aprakstīja kā iestādi, kurā nebija speciālu apstākḷu psihiski slimo ārstēšanai un aprūpei (bet bija pieminēts dārzs, kam toreiz piešķīra lielu terapeitisku nozīmi). ${ }^{44}$ Tā bija izvietota trijās divstāvu ēkās un nesen izbūvētā flīgelī. Iestādes direktors

40 Steinberg, Holger, Matthias C. Angermeyer. "Emil Kraepelin's Years at Dorpat as Professor of Psychiatry in Nineteenth-Century Russia." History of Psychiatry 12, no. 47 (August 2001): 297-327. doi:10.1177/0957154X0101204703. Te var atcerēties kņazu Ļevu Nikolajeviču Miškinu - F. Dostojevska romāna "Idiots” (1868) galveno varoni, kas epilepsijas dēl piecus gadus ārstējās Šveices klīnikā.

41 Fatikh Artvinli, "Insanity, belonging and citizenship: mentally ill people who went to and/or returned from Europe in the Late Ottoman Era," History of Psychiatry 27, no. 3 (2016): 268-277, doi:10.1177/0957154X16642995.

42 Iukhan Luiga, Prizrenie dushevnobol'nykh v Pribaltiiskom krae, Istoriya prizrenia dushevnobol'nykh v ostzejskih guberniyah, 107.

43 Rīgā psihiski slimo aprūpe prikaza Dievam tīkamās iestādēs sākās agrāk 1785. gadā, Rīgas Citadelē. Sk. A. Tobin, Prizrenie bednykh v g. Rige (Riga, 1895), 227. Prikaza vājprātīgo nodaḷa tika dibināta 1810. gadā. Sk.: Iukhan Luiga, Prizrenie dushevnobol'nykh v Pribaltiiskom krae. Dissertatsiia na zvanie doktora meditsiny (Iurj'ev, 1904), Istoriya prizrenia dushevnobol'nykh v ostzejskih guberniyah, 3. Vēlāk Dievam tīkamās iestādes no Citadeles tika pārceltas uz jaunām plašākām telpām Aleksandra Augstumos.

44 Heinrich Laehr und Max Lewald, Die Heil- und Pflegeanstalten für PsychischKranke des deutschen Sprachgebietes am 1. Januar 1898 (Berlin, Verlag von Georg Reimer, 1899), 235. 
bija Vladimirs Koltipins ${ }^{45}$ (Wladimir Koltypin, citā avotā - Koltypin Eugen Wladimirowitsch, 1889-?), ${ }^{46}$ ordinators - Jūliuss Vīzenbergs (Julius Wiesenberg). 1896. gadā iestādē tika aprūpēti 227 slimnieki (122 vīrieši un 105 sievietes), neviens nebija nomiris.

Ieskatīties iestādes dz̄ivē var, lasot tā laika presi. Ziṇas par iemītnieku (arī arestantu no darba un pārmācības namiem) bēgšanu un viņu meklēšanu bija bieža parādība. Piemēram, avīzē Lifl'andskie gubernskie novosti jeb Livländische Gouvernements-Zeitung 1864. gada 9. oktobrī tika zinots par kāda 25 gadus veca zemnieka Gindrika Tamma, kuram bija piespriesti deviņi gadi aresta, mukšanu no Aleksandra Augstumu darba nama. Bēglim bija īpašas pazīmes - "kāju vājums" (bērnu cerebrālās triekas sekas; polineiropātija? - autoru piezīme); vīrietis bija ǵērbies vecā šinelī, uz viņa krekla bija zīmogs Alexandreshöhe. ${ }^{47} \mathrm{Kā}$ redzams, fiziskie trūkumi netraucēja vīrietim doties prom no penitenciārās iestādes.

Divus gadus vēlāk avīzē rakstīts par diviem meklēšanā pasludinātiem bēgḷiem - Prūsijas padoto Germanu Kirstenu un Šveices padoto Joganu Šreteru -, lai par uzturēšanos Aleksandra Augstumu iestādēs no Kirstena piedzītu 2 rublıs un 40 kapeikas un no Šretera - 48 rubḷus un 90 kapeikas. ${ }^{48}$ Gadiem ejot, bēgul̦ošana turpinās: 1890. gada jūlijā tiek ziņots par arestanta Kārḷa Pūces meklēšanu (28 gadi, zilām acīm, rudmatis, runā gan krievu, gan vācu, gan igauņu (po chuhonski) valodā). ${ }^{49}$

1887. gada 2. oktobrī avīzē vēstīts, ka Rīgā tika aizturēta un uz dziednīcu nogādāta kāda nezināmā (sirmiem matiem, ap piecdesmit gadu vecumu), kura uzdevās par senas vācbaltiešu dzimtas pārstāvi baronesi Fītinghofu, un ka policija uzsākusi viṇas piederīgo meklēšanu. ${ }^{50} \mathrm{Citu}$

45 Lifl'andskie gubernskie vedomosti / Livländische Gouvernements-Zeitung, no. 138 (22.12.1904), 957, https://dea.digar.ee/cgi-bin/dea? $\mathrm{a}=\mathrm{d} \& \mathrm{~d}=$ livzeitung19041222.2.2

46 Brennsohn, Isidorus: Die Aerzte Livlands von den ältesten Zeiten bis zur Gegenwart Mitau 1905, 247.

47 Lifl'andskie gubernskie vedomosti / Livländische Gouvernements-Zeitung, no. 15 (09.10.1864), pielikums, https://dea.digar.ee/cgi-bin/dea?a=d\&d=livzeit ung18641009.2.8

48 Lifl'andskie gubernskie vedomosti / Livländische Gouvernements-Zeitung, no. 90 (13.08.1886), 489, https://dea.digar.ee/cgi-bin/dea? $\mathrm{a}=\mathrm{d} \& \mathrm{~d}=$ livzeitung18860813.2.2.1

49 Lifl'andskie gubernskie vedomosti / Livländische Gouvernements-Zeitung, no. 80 (20.07.1890), 423, https://dea.digar.ee/cgi-bin/dea?a=d\&d=livzeitung18900720.2.2.7

50 Lifl'andskie gubernskie vedomosti / Livländische Gouvernements-Zeitung, no. 109 (02.10.1887), 691, https://dea.digar.ee/cgi-bin/dea? $\mathrm{a}=\mathrm{d} \& \mathrm{~d}=$ livzeitung18871002.2.2.1 
dienu avīzē izsludināta Mītavas (Jelgavas) mietpilsones Annas Juliānes Steikovskas meklēšana: viņa ir jānopratina saistībā ar viltotu ziņojumu, uz kura pamata viņa savulaik tika uzņemta iestādēs ${ }^{51}$ (iespējams, sieviete tika apmelota par nodarbošanos ar prostitūciju un venerisko slimību izplatīšanu). 1902. gadā iestāde meklēja ārstu ordinatoru, garantējot līdz 900 rubliem lielu gada algu, dzīvokli "ar apgaismojumu un apkuri”. ${ }^{52}$ Vēl aizvien Aleksandra Augstumos tika uzņemti arī bērni - 1909. gadā avīzē ziņots par kāda aptuveni deviņus gadus veca garīgi atpalikuša pacienta vecāku meklēšanu. ${ }^{53,54}$

2. Rīgas pilsētas Sarkankalna psihiatriskā slimnīca (Rotenberga ārstēšanas iestāde) jeb Brucera klīnika (dibināta 1862. gadā). 1872. gadā, kad to nopirka Rīgas pilsēta, slimnīcas telpas bija bēdīgā stāvoklī un iestādē atradās 61 slimnieks; savukārt 1904. gadā tur bija jau 342 gultas. ${ }^{55}$ Lai cīnītos ar iestādes pārpildīšanos, pilsēta nopirka un slimnīcai pievienoja patversmes Valdgeima un Birkenhofa (tās atradās pie slimnīcas robežas Sarkandaugavas virzienā). ${ }^{56}$

51 Lifl'andskie gubernskie vedomosti / Livländische Gouvernements-Zeitung, no. 76 (20.07.1888), 482, https://dea.digar.ee/cgi-bin/dea? $\mathrm{a}=\mathrm{d} \& \mathrm{~d}=$ livzeitung18880720.2.2.1

52 Lifl'andskie gubernskie vedomosti / Livländische Gouvernements-Zeitung, no. 132 (04.12.1902), 832, https://dea.digar.ee/cgi-bin/dea?a=d\&d=livzeitung19021204.2.5

53 Lifl'andskie gubernskie vedomosti / Livländische Gouvernements-Zeitung, no. 67 (01.07.1909), 522, https://dea.digar.ee/cgi-bin/dea?a=d\&d=livzeitung19090701.2.14

54 Diemžēl šī prakse - VSIA “Rīgas psihiatrijas un narkoloǵijas centrs” stacionārā nepilngadīgus pacientus ievietot vienā nodal̦ā ar pieaugušajiem - ir saglabājusies līdz pat mūsdienām, lai gan Eiropas Padomes un Eiropas Komitejas Astotajā vispārējā ziņojumā par spīdzināšanas un necilvēcīgas vai pazemojošas rīcības vai soda novēršanu ir rakstīts, ka "ir noteikti jābūt stingri reglamentētai kārtībai, kā aizsargāt noteiktus psihiatriskos pacientus no citiem pacientiem, kas varētu tiem nodarīt kaitējumu. [..] Ir jāparedz īpaši pasākumi mazaizsargātām pacientu grupām, piemēram, pusaudži ar īpašām vajadzībām vai/un garīgiem traucējumiem nebūtu jāizmitina kopā ar pieaugušiem pacientiem”. Sk.: Eiropas Padome, Eiropas Komiteja, Spīdzināšanas un necilvēcīgas vai pazemojošas rīcības vai soda novēršanai, Piespiedu ievietošana psihiatriskās ārstniecības iestādēs. Izvilkums no Astotā vispārējā ziņojuma, 1998, 2. lpp. (https://rm.coe. int/16806cd434). Šo viedokli un novērojumus apstiprina arī tiesībsargs ziņojumos par Latvijas bērnu psihoneirolog̣isko nodaļu apsekošanas rezultātiem: http://www.tiesibsargs.lv/lv/pages/petijumi-un-publikacijas/gadazinojumi/gada-zinojumi

55 Iukhan Luiga, Prizrenie dushevnobol'nykh v Pribaltiiskom krae, Istoriya prizrenia dushevnobol'nykh v ostzejskih guberniyah, 107.

56 Parcival Lieven, Ernst Hollander, Julius Schroeder, Festschrift zum 25jährigen Jubiläum des Direktors Dr. med. Th. Tiling (Rīga, 1909), 72. Situationsplan der Anstalt Rothenberg. 
Gultasvietu trūkuma dēḷ nabadzīgie slimnieki, kam bija steidzami nepieciešama ievietošana stacionārā, līdz 1887. gadam atradās t. s. vājprātīgo patversmē - pie pilsētas cietuma rezerves lazaretes Rēveles ielā (mūsdienu Tallinas iela). 1887. gada 1. maijā tika atklāta Pagaidu stacija (Zwischenstation - jādomā, ka turpat t. s. Šmita mājās) ${ }^{57}$ - slimnīcas nodaḷas tipa iestāde ar 10 gultām pilsētas slimnīcu pārvaldes pārziṇā; 1888. gada decembrī to pārvietoja uz Rotenbergu un paplašināja līdz 12 gultām. ${ }^{58}$ Tur nogādāja policistu aizturētos psihiski slimos līdz brīdim, kamēr policisti noskaidroja viņu teritoriālo piederību. Bieži vien te atradās sabiedriski bīstami pacienti ar īpaši smagām slimības formām. ${ }^{59}$ 1892. gadā tur strādāja viena uzraudze un divi uzraugi un tika aprūpēti 49 slimnieki. ${ }^{60}$

3. Psihiatriskā nodaḷa Rīgas Kara hospitālī (atklāta 1895. gadā). Par tās ordinatoru kḷuva Fjodors Gadziatskijs (1860-?). ${ }^{61}$

4. Dorpatas / Jurjevas Universitātes psihiatriskā klīnika (dibināta 1881. gadā) jeb Nervu un psihisko slimību klīnika ar 100 gultām.

5. Šēnfelda nervu privātklīnika (dibināta 1898. gadā) Rīgā ar 50 gultām.

6. E. Sokolovska privātklīnika nervu slimniekiem Rīgā (dibināta 1900. gadā) ar 40 gultām.

7. Patversme Marienhof V̄ilandes apriņķ̄î (Fellin, Jämejala; dibināta 1897. gadā, 100 gultu).

8. Vispārējā profila zemstes slimnīca un vājprātīgo nams Ārensburgā (tagad Kuresāre; Sāremā bija viena no Vidzemes guberņas salām, ko Krievijas impērija pievienoja 1721. gadā), ${ }^{62}$ kas atradās muižniecības pārvaldībā. 1860. gadā slimnīcā ārstējās viens vīrietis un 139 sievietes, vājprātīgo namā - viens vīrietis un septiņas sievietes. Iestāžu uzturēšana 1860. gadā izmaksāja 3267 rublılus. ${ }^{63}$

57 Namīpašnieks - Kārlis Šmits.

58 A. Tobin, Prizrenie bednykhv g. Rige, 120.

59 Iukhan Luiga, Prizrenie dushevnobol'nykh v Pribaltiiskom krae, Istoriya prizrenia dushevnobol'nykh v ostzejskih guberniyah, 52-53.

60 A. Tobin, Prizrenie bednykhv g. Rige, 117-118.

61 Jacqueline Lee Friedlander, Psychiatrists and Crisis in Russia, 1880-1917 (Berkeley: University of California, 2007), 100.

62 A. Blagoveshchenskii, Ostrov Ezel', gorod Arensburg i ikh dostoprimechatel'nosti, 28.

63 F. Veimarn, Materialy dlia geografii i statistiki Rossii, sobrannye ofitserami General'nogo shtaba. Lifliandskaia guberniia (Sankt-Peterburg: Tip. R. Golike, 1864), 628. 
9. Vidzemes guberņas Ārstu biedrības organizētā pagaidu patversme Rotenbergas (vēlākā Sarkankalna) slimnīcas ārstu Augusta Kristofa Merklina (August Christoph Mercklin) un Alberta Bēra (Albert Behr, 1860-1919, Dr. med. 1891) vadībā - pastāvēja īslaicīgi 19. un 20. gadsimta mijā un sniedza palīdzību nelielam skaitam slimnieku, kuriem pietrūka vietu Aleksandra Augstumos vai Rotenbergā. ${ }^{64}$

Psihiski slimajiem Vidzemes guberṇā aprūpi sniedza arī privātās labdarības iestādes. Piemēram, Sarkanā Krusta māsa Šarlota MartinovaBlumberga Rīgā nodibināja Neārstējami plānprātīgo un somatiski vājo patversmi. Tās statūti bija apstiprināti 1895. gada 6. maijā, paredzot, ka vienā no Rīgas priekšpilsētām 25 gultas tiek uzturētas par dibinātājas līdzekḷiem. ${ }^{65}$ Abu dzimumu neārstējami slimo aizgādība patversmē ( $p o p e-$ chenie) attiecās uz mierīgajiem (tikhie) plānprātīgajiem vai idiotiem un nevarīgajiem (driakhlye), kas vecuma vai veselības stāvokḷa dēl nevarēja iztikt bez pastāvīgas aprūpes vai kam bija nepieciešama daḷēja uzraudzība. Medicīniskajā un administratīvajā ziņā patversme atradās ārsta pārzin̄ā, kurš atbildēja par vispārējo kārtību iestādē. Par galvenā ārsta iecelšanu, kā arī par jebkādām izmaiņām patversmes izveidošanā dibinātājai bija pienākums ziņot Vidzemes guberņas valdes Ārstniecības nodaḷai. Maksa (ap 30-60 rubḷiem mēnesī) tika noteikta katrā atsevišķā gadījumā individuāli, vienojoties dibinātājai ar slimniekiem vai piederīgajiem.

Palīdzību dažādām iedzīvotāju grupām sniedza arī vairākas Vidzemes guberņas sabiedriskā labuma organizācijas. ${ }^{66}$ Terēzas Placs (Therese Platz) ārstnieciski pedagoǵiska iestāde Zassenhofā (Zasulaukā pie Rīgas), vēlāk - ārstnieciski pedagoǵiska iestāde no lēkmēm sirgstošajiem, mazspējīgajiem, plānprātīgiem un idiotiem. Iestāde tika dibināta 1854. gadā, tās statūtus apstiprināja 1853. gada 9. septembrī, un tā bija domāta vācu iedzīvotājiem. Iestādes mērķis bija attīstīt audzēkņu prāta spējas, cik nu tas ir iespējams, un "padarīt viņu dzīvi priecīgāku un apkārtējiem vieglāk panesamu”. Tā bija pirmā psihiatriskā iestāde bērniem Krievijā, vēlāk tā kḷuva par privāto dziedn̄icu plānprātīgajiem un epileptiķiem. Iestāde paplašinājās

64 Iukhan Luiga, Prizrenie dushevnobol'nykh v Pribaltiiskom krae, Istoriya prizrenia dushevnobol'nykh v ostzejskih guberniyah, 68-76.

65 Latvijas Nacionālā arhīva Latvijas Valsts vēstures arhīvs (turpmāk LNA LVVA), 1288-4-106, 21.

66 Petr' Rutskii, Obshchestva Lifliandskoi gubernii (Riga: Izdanie Br. Bashmakovykh, 1900), 37-38. 
līdz 80 gultām un pastāvēja "līdz revolūcijai", domājams, līdz 1917. gadam. To kā "patversmi idiotiem" (Idioten Anstalt) bija dibinājis Fridrihs Placs, kurlmēmo skolotājs no Kēnigsbergas, un tā bija pārpildīta ar nabadzīgiem bērniem. Pieticīgo resursu dēḷ bērnus nebija iespējams kvalitatīvi aprūpēt, taču ir skaidri zināms, ka bērni tika mācīti rakstīt un lasīt. 1862. gadā F. Placs sastādīja un izdeva īpašu albumu ar iestādes audzēkṇu gì̄metnēm.

No 1864. gada patversmes pārvaldību pārņēma atraitne Terēza Placs. 1874. gada decembrī iestādi pārvaldīja Placs kundze; par ārstu strādāja Vikerts (Arzt Collegienrath Dr. Wiehert). ${ }^{67}$ 1879. gadā atraitne Terēza Placs iegādājās zemes gabalu Zassenhofā un patversmi pārdēvēja par ārstnieciski pedagoǵisku iestādi. ${ }^{68}$ 1898. gadā iestāde atradās Geldingerstrasse 35 (tagadējā Kuldīgas ielā 43); tajā strādāja ārsti Vikerts un Huff, un Dr. E. von Rautenfeldt konsultēja bērnus ar krampjiem. ${ }^{69,70} 1902$. gadā tajā tika aprūpēti 32 pārtikušo iedzīvotāju bērni. ${ }^{71}$ 1904. gadā patversmes nosaukums bija "Terēza" un tā piederēja ārstam Fermanim. Vēlāk iestāde nosaukta par Defektīvo bērnu patversmi (1920-1934), pēc tam - par Rīgas pilsētas bērnu namu, kur jau tolaik tika izmantotas Montesori un Dekrolī metodes. ${ }^{72}$

Salīdzinājumam - pēc M. Štāla domām, pirmā valsts, kas sāka pievērst uzmanību atpalikušo bērnu skološanai, bija Vācija (jo, mācoties kopā ar pārējiem bērniem, nesekmības dēl̦ viņus parasti uzskatīja par slinkiem, dažreiz izslēdza no skolas; no skolas izmestie bērni kḷuva par sabiedrības padibenēm). Tur 1863. gadā nodibināja pirmo skolu garīgi

67 Heinrich Laehr, Die Heil- und Pflegeanstalten für Psychisch-Kranke in Deutschland: der Schweiz und den benachbarten deutschen Ländern (Berlin: Vorlag von Georg Reimer, 1875), 109, https://ia802909.us.archive.org/22/items/39002086344885.med. yale.edu/39002086344885.med.yale.edu.pdf

68 Petr' Rutskii, Obshchestva Lifliandskoi gubernii, 37-38.

69 Heinrich Laehr, Max Lewald, Die Heil- und Pflegeanstalten für Psychisch-Kranke des deutschen Sprachgebietes am 1. Januar 1899, 235.

70 Sīkāku informāciju par iestādes darbu var meklēt atskaitēs: T. Platz, Mitteilungen aus der heilpädagogischen Anstalt (Riga, 1872), 43, kā ar̄̄ šādos izdevumos: Fortsetzung der Mittheilungen über die Heilpädagogische Anstalt für Krampfleidende, Geistigzurückgebliebene, Schwachsinnige und Idioten von Frau Therese Platz / Heilpädagogischen Anstalt der Frau Therese Platz.

71 Iukhan Luiga, Prizrenie dushevnobol'nykh v Pribaltiiskom krae, Istoriya prizrenia dushevnobol'nykh v ostzejskih guberniyah, 79.

72 M. Štāls, Mūsu dzīves pabērni, viņu audzināšana un mācī̌šna (Rīga: Valters un Rapa, 1936), 400. 
atpalikušajiem; 1898. gadā Vācijā bija jau 52 tādas skolas. Vācijas piemēram sekoja pārējās valstis. Pēc M. Štāla domām, mazāk speciālā pedagogija bija attīstīta Austrijā, Itālijā, Ziemel̦amerikā, vissliktākajā stāvoklī tā bija Krievijā (pirms 1. pasaules kara speciālās skolas bija tikai Rīgā, Kijevā un Petrogradā). ${ }^{73}$

Jāatzīmē, ka Terēza Placs bija īsta speciālās pedagoǵijas pioniere un entuziaste. Viṇas vārds bija minēts jau 20. gadsimta sākumā izdotajā grāmatā par speciālo izglītību. Viṇa pati uzrakstīja grāmatas "Was ist idiotie?" (Rīga, 1876) un "Die Heilpflege und Erziehung zurückgebliebener, schwachsinniger und idiotischer Kinder" (Leipzig, Richter, 1880, 1882, 166 lpp.). 1880. gada septembrī Štutgartē viņa kā vienīgā praktiskāa speciāliste uzstājās garīgās atpalicības jautājumiem veltītā konferencē un izturēja asu savu ideju kritiku un negatīvu attieksmi, ko pauda teorētiķi (vīrieši). ${ }^{74}$

Apskatāmajā laika posmā Vidzemē darbojās arī Vidzemes guberņas psihiski slimo aizgādības sabiedrība, kas bija domāta vāciešiem. Tā tika dibināta 1898. gadā, un statūti bija apstiprināti 1899. gadā. Sabiedrības uzdevums bija sameklēt resursus un iespējas to slimnieku aprūpei, kuriem ārstniecības iestādēs pietrūka vietu vai nebija līdzekḷu to apmaksai.

Trūcīgos Rīgas iedzīvotājus pēc iespējas centās nodot ǵimenes aprūpē par pilsētas līdzekḷiem - 1897. gadā bija reǵistrēti 84 tādi slimnieki un viņu uzraudzībai pilsēta algoja ārstu; ${ }^{75}$ tāpat par Rīgas Nabago direktorijas līdzekḷiem slimnieki tika ievietoti dažādās iestādēs ārpus pilsētas Dorpatas / Jurjevas Universitātes klīnikā, Virtembergā (Vācija), Visu sirgstošo slimnīcā Sanktpēterburgā. ${ }^{76}$

Jāpiebilst, ka vēl 1812. gadā, kad pēc kara bija nodedzinātas Rīgas priekšpilsētas un daudzi iedzīvotāji palika bez pajumtes un darba, pieauga neuzraudzīto, ubagojošo bērnu skaits. Tādēl Rīgas pilsoņi nolēma viņiem nodibināt īpašu patversmi pēc Vācijas parauga - morāli paklīdušo jeb morāliski defektīvo bērnu audzināšanas (mūsdienās teiktu - novārtā

73 M. Štāls, Mūsu dzīves pabērni, viņu audzināšana un mācīšana (Rīga: Valters un Rapa, 1936), 380.

74 Sieglind Luise Ellger-Rüttgardt, Geschichte der Sonderpädagogik: Eine Einführung, 2. Auflage, 2019, 384. S, 226.

75 Iukhan Luiga, Prizrenie dushevnobol'nykh v Pribaltiiskom krae, Istoriya prizrenia dushevnobol'nykh v ostzejskih guberniyah, 55-56.

76 A. Tobin, Prizrenie bednykhv g. Rige, 119. 
pamesto un no vardarbības cietušo bērnu aprūpes) iestādi. Tikai 1839. gadā Rīgas pilsonis Radekijs iestādes vajadzībām piedāvāja savu muižiṇu Hermelingshof pie Strazdumuižas. Iestādi atklāja 1839. gadā 30. martā, un kā pirmais audzēknis tika uzņemts Fridrihs Arends, ārlaulības bērns, kas par savu tēvu sauca kādu Krievijas armijas virsnieku. Iestādē uzṇēma abu dzimumu luterticīgus bērnus. Kad bija jau 32 audzēkṇi, iestādei bija nepieciešamas plašākas telpas un 1840. gadā Rīgas tirgotājs Loezevics ${ }^{77}$ nopirka Pleskodāles muižiṇu ar 9 pūrvietām zemes. Rīgas pilsēta iestādi pabalstīja un nodeva tās rīcībā 99 pūrvietas neizkoptas zemes. Pie iestādes izveidoja pamatskolu. Tā aizsākās nepilngadīgo labošanas un audzināšanas iestāžu vēsture Latvijā. ${ }^{78}$

Kurzemes guberṇā 1904. gadā darbojās vismaz četras iestādes.

1. Kurzemes gubernas Sabiedriskās aizgādības kolēǵijas (prikaza) slimnīcas psihiatriskā nodaļa ar 80 gultām Mītavā (Jelgavā). Jāsaka, ka par šo iestādi pagātnes pētniekiem bija maz zināms. Piemēram, Krievijas Ģenerālštāba apakšpulkvedis A. Oranovskis, detaḷās aprakstot Kurzemes guberņas sociālās palīdzības iestādes, sabiedriskā labuma organizācijas un medicīniskās palīdzības resursus (apkopojot datus līdz 1857. gadam ieskaitot), tieši norāda, ka guberņā nav vājprātīgo nama (un nav arī darba nama un pārmācības nama). Viņš nemin nevienu iestādi vai labdarības organizāciju, kas koncentrētos uz palīdzības sniegšanu psihiski slimajiem vai plānprātīgajiem. ${ }^{79}$ A. Stogs savā darbā par sabiedriskās aizgādības pirmsākumiem Krievijā, aprakstot Kurzemes prikazu 1810. un 1816. gadā, nosauc vairākas Dievam tīkamās iestādes, neko neminot par psihiatrisko nodaḷu. ${ }^{80}$

77 Iespējams, te ir domāts mācītājs Lezevics (Georg Wilhelm Lösewitz, Can. Theol., 1808-1888). No 1850. gada viņš dzīvoja Rīgā kā privātpersona un darbojās labdarības nozarē, tostarp 1851. gadā dibināja Magdalēnas patversmi ("morāliski pagrimušām meitenēm”) - ceturto vecāko evaṇgēēisko Magdalēnas patversme Eiropā. Sīkāk sk. Marina Loseviča, Vladimirs Kuzṇecovs "Magdalēnas patversme Rīgāa," Latvijas Universitātes raksti, Zinātņu vēsture un muzejniecība, 800 (2014): 135-157.

78 M. Štāls, Mūsu dzīves pabērni, viņu audzināšana un mācīšana, 414.

79 A. Oranovsyi, Materialy dlia geografii i statistiki Rossii, sobrannye ofitserami General'nogo shtaba. Kurl'andskaia guberniia (Sankt-Peterburg: Tipografiia departamenta gerenal'nogo shtaba, 1862), 420.

80 Aleksej D. Stog, O obschestvenom prizrenii v Rossii, Izdano pri Ministerstve Policii, v 4 chast'ah (Sanktpeterburg, 1818). Pervaja chast', Tabel' o sostojanii prikazov obschestvenogo prizrenija v pervoj polovine 1810 goda, Tabel' o sostojanii prikazov obschestvenogo prizrenija v 1816 godu. (Lapas nav numurētas.) 
Ar̄̄ dr. Heinrihs Lērs (Heinrich Laehr) savā grāmatā uzsver, ka Kurlandes guberṇā nav vājprātīgo nama per se, bet gan tikai prikaza slimnīcas nodaļa, ${ }^{81}$ tādēl līdz 1869. gadam psihiski slimie tika aprūpēti vispārīga profila slimnīcā, pēc tam tika izveidota atsevišksa Psihiatrijas nodaļa. Psihiatrs Juhans Luiga nespēja noskaidrot iestādes dibināšanas laiku, tikai apgalvoja, ka ap 1840. gadu prikaza slimnīcas nodaļā tika aprūpēti 15 slimnieki un iestādes stāvoklis bija tikpat bēdīgs kā prikaza iestādēs citur impērijā. ${ }^{82}$ 1853. gadā tur tika aprūpēti vien septiņi slimnieki, visi - zemnieku šķiras; augstāko šķiru slimniekus ievietoja Aleksandra Augstumos vai veda uz Sanktpēterburgu. ${ }^{83}$

1873. gadā psihiatrijas nodaḷā ārstējās 101 slimnieks (64 vīrieši, 37 sievietes), nomiruši 10 (seši vīrieši, četras sievietes). Personālā ietilpa ārsts Karl Wilhelm Gramkan (1806-1890), ${ }^{84}$ ordinators - Dr. med. Stephany Edmunds (1836-?), ${ }^{85}$ viens uzraugs un viena uzraudze, pieci slimnieku kopēji un divas kopējas, divi feldšeri. ${ }^{86}$ Šāds vīriešu slimnieku pārsvars Kurzemes psihiatriskajā iestādē, kas - atšķirībā no Aleksandra Augstumiem - bija pilnībā pasargāta no penitenciārās funkcijas pildīšanas, apgāž Jakobija apgalvojumu, ka vīriešu pārsvars Krievijas psihiatriskajās iestādēs, salīdzinot ar Vakareiropu, skaidrojams ar sodīšanas un/vai izolācijas funkciju.

Latvijas medicīnas vēsturnieks profesors A. Vīksna apgalvo, ka Kurzemes prikaza Dievam tīkamās iestādes darbojās laikposmā no 1825. līdz 1918. gadam un, līdzīgi kā Aleksandra Augstumus, sākotnēji tur bija pārmācības nams, darba nams, nabagmāja un garīgo slimnieku nodaļa, dzemdību un acu slimību nodaḷa. Arī šì iestāde pakāpeniski atbrīvojās no penitenciārām funkcijām, kḷūstot par slimnīcu; no 1826. gada tur pastāvēja Latvijā pirmā vecmāšu skola. ${ }^{87}$ Iestādes vēsture vēl gaida savus pētniekus.

81 Heinrich Laehr, Die Heil-und Pflegeanstalten für Psychisch-Kranke in Deutschland, 83.

82 Iukhan Luiga, Prizrenie dushevnobol'nykh v Pribaltiiskom krae, Istoriya prizrenia dushevnobol'nykh vostzejskih guberniyah, 97.

83 Ibid., 5.

84 Isidorus Brennsohn, Die Aerzte Kurlands vom Beginn der herzoglichen Zeit bis zur Gegenwart: ein biographisches Lexikon nebst einer historischen Einleitung über das Medizinalwesen Kurlands, 2. Ausg. (Riga: Verlag von Ernst Plates A/G, 1929), 89-90.

85 Ibid., 186.

86 Heinrich Laehr, Die Heil-und Pflegeanstalten für Psychisch-Kranke in Deutschland, 83.

87 Arnis Vīksna. "Medicīnas administratīvās sistēmas Latvijā 19. gadsimtā un 20. gadsimta sākumā," Latvijas Universitātes raksti. Zinātņu vēsture un muzejniecība. 809 (2015): 129-144. 
2. Patversme "Tabor" plānprātīgajiem un epileptiķiem (dibināta 1887. gadā) ar 212 gultām. Par 500 rubliem gadā Taborā tika aprūpēti desmit Vidzemes guberņas slimnieki.

3. Dr. Girgensona iestāde (Familienpensionat) sešiem slimniekiem (dibināta 1874. gadā). Tajā netika uzṇemti īpaši trokšnaini un netīrīgi slimnieki, aprūpi realizēja divi uzraugi un trīs uzraudzes. ${ }^{88}$

4. Psihiatriskā dziednīca psihiski slimajiem patversmes "Tabor" paspārnē (dibināta 1901. gadā) ar 60 gultām.

Igaunijas guberņā darbojās trīs iestādes. ${ }^{89}$

1. Igaunijas guberņas Sabiedriskās aizgādības kolēgijas psihiatriskā nodaļa jeb prikaza vājprātīgo nams Rēvelē (dibināts 1802. gadā) ar 18 gultām.

2. Igaunijas guberņas Psihiski slimo aizgādības sabiedrības dziednīca “Zevald” (dibināta 1903. gada 31. oktobrī) netālu no Rēveles ar 100 gultām. Dziednīca bija moderni aprīkota, maksa bija 25 rubḷi mēnesī, pansionāta nodaḷā - 75 rubḷi mēnesī. Nabadzịgajiem Igaunijas guberņas slimniekiem bija atlaides, un tie maksāja tikai 15 rubļu mēnesī, bet galēja trūkuma gadījumā ārstējās bez maksas (uzsvērts, ka bezmaksas gultas nekādā gadījumā nedrīkst būt vairāk par trešdaļu no kopējā gultu skaita).

3. Daktera Veisa nervu slimnieku privātklīnika Rēvelē (dibināta 1902. gadā) ar 20 gultām.

Igaunijas guberņas iedzīvotājiem bija pieejamas vēl vairākas iespējas - Guberņas nabago slimnīcas Psihiatriskā nodaļa (sešas gultas), kā ar̄̄ 8-9 slimnieki tika aprūpēti vispārējā profila slimnīcās, 12 gultas mierīgajiem slimniekiem žēlsirdīgo māsu patversmē, ${ }^{90}$ Dorpatas Sabiedriskās aizgādības kolēgijas (prikaza) slimnīca (60 gultu 1864. gadā) un Sanktpēterburgas Medicīnas un ķirurǵijas akadēmija. 1875. gadā H. Lērs rakstīja, ka Rēvelē māsu diakoniķu slimnīcā bija dažas vietas psihiski slimajiem iespējams, ar to domāta iepriekšminētā žēlsirdīgo māsu patversme. ${ }^{91}$

Psihiatrs Luiga, 1902. gada vasarā veicot Jurjevas apgabala luterticīgo lauku iedzīvotāju apsekošanu, atrada 739 psihiatriskus slimniekus - no

88 Heinrich Laehr, Die Heil- und Pflegeanstalten für Psychisch-Kranke in Deutschland, 182-183.

89 Iukhan Luiga, Prizrenie dushevnobol'nykh v Pribaltiiskom krae, Istoriya prizrenia dushevnobol'nykh v ostzejskih guberniyah, 107.

90 Ibid., 93.

91 Heinrich Laehr, Die Heil-und Pflegeanstalten für Psychisch-Kranke in Deutschland, 172. 
tiem 12 tika turēti pie ķēdes, 21 slimnieks atradās krātiņā, 12 slimnieki tika sisti un tikai 74 slimnieku uzturēšanas apstākḷi bija apmierinoši. ${ }^{92}$

\section{Emīls Krēpelīns Dorpatas Universitātes Nervu un psihisko slimību klīnikā}

Dorpatā ārsts Eduards Georgs fon Vāls (Eduard Georg von Wahl, 1833-1890) 1877. gada 4. martā ar līdzstrādniekiem, balstoties uz sabiedrības un individuālās labdarības principiem (kopā vien pieci aktīvisti), atklāja psihiatrisku patversmi 6-8 slimniecēm. Dorpatas kopienai vienas slimnieces uzturēšanās maksāja 18 rubḷu mēnesī. ${ }^{93}$ Vēlāk aktīvisti panāca psihiatriskās slimnīcas nodibināšanu, kuras pārvaldīšanu nodeva Dorpatas Universitātei. Tā 1881. gada 16. aprīlī tika dibināta Dorpatas Universitātes Nervu un psihisko slimību klīnika. Par tās direktoru kḷuva Hermanis Eminghauss (Hermann Emminghaus, 1845-1904) - pirmais Dorpatas Universitātes psihiatrijas profesors, viens no bērnu psihiatrijas pamatlicējiem pasaulē.

Dorpatas klīnika drīz iekaroja popularitāti Krievijas augstākajā sabiedrībā. Populāras bija arī klīnikas vadītāja Eminghausa lekcijas psihiatrijā. No pašiem pirmsākumiem Eminghauss atteicās no jebkādas slimnieku mehāniskās ierobežošanas un ieviesa darba terapiju - toreiz modernu ārstēšanas metodi -, kā arī sekoja, lai slimības vēstures būtu kārtīgi pierakstītas. Dorpatā profesors turpināja vākt materiālus savai monogrāfijai "Die psychischen Störungen des Kindesalters", no kā var secināt, ka klīnikā uzņēma arī bērnus. Eminghauss, nervozs cilvēks, noteikti nebija cīnītājs, tādēl sarunās ar Krievijas ierēdņiem nespēja konsekventi aizstāvēt savu viedokli un panākt savu ideju îstenošanu.

1886. gada ruden̄̄ Eminghauss pieñēma Freiburgas Universitātes jaunizveidotās Psihiatrijas katedras vadītāja amatu. Viņš bija pārlaimīgs, jo varēja no Dorpatas "tuksneša" atgriezties Vācijā un strādāt, neizjūtot valodas problēmas un nepieciešamību cīnīties ar Krievijas birokrātiju. Atstājot posteni, starp četriem potenciālajiem kandidātiem uz savu vietu profesors nosauca Emīlu Krēpelīnu un Augustu Kristofu Merklinu, kas

${ }^{92}$ Iukhan Luiga, Prizrenie dushevnobol'nykh v Pribaltiiskom krae, Statistika dushevnobol'nykh $v$ Pribaltiiskom krae, 46.

${ }^{93}$ Iukhan Luiga, Istoriya prizrenia dushevnobol'nykh v ostzejskih guberniyah, 59. 
1878.-1879. gadā strādāja Sarkankalnā. ${ }^{94}$ Eminghauss lobēja Krēpelīnu jaunais psihiatrs no Drēzdenes tika izvēlēts, citus potenciālos pretendentus neiztaujājot. Sevišksi tika ņemta vērā Krēpelīna pieredze Leipcigā, strādājot pie Paula Emīla Fleksiga (Paul Emil Flechsig, 1847-1929), Vilhelma Erba (Wilhelm Erb, 1840-1921) un Vilhelma Vunda (Wilhelm Wundt, 18321920). Bija atzīts, ka Krēpelīnam nav bagātīgas klīniskā darba pieredzes, toties viņš ir l̦oti pieredzējis pētniecībā (eksperimentālajā psihologijāa, elektroterapijā u. c.).

Fakultātes vadība ignorēja faktu, ka Fleksigs Krēpelīnu atlaida, apvainojot nevērībā pret pacientiem (iespējams, tādēḷ, ka apvainojumi bija nepamatoti), un viña curriculum vitae pierakstīja pusotru mēnesi pēc prakses Leipcigas Psihiatriskajā slimnīcā. ${ }^{95}$ Rezultātā ministrija apstiprināja Krēpelīnu kā pilnu psihiatrijas profesoru un Dorpatas Universitātes Nervu un psihisko slimību klīnikas vadītāju no 1886. gada 1. jūlija ar algu 2400 rubḷu gadā. Salīdzinājumam - Aleksandra Augstumos direktors pelnīja 1000 rubl̦u gadā, divi jaunākie ordinatori - katrs 600 rubḷu gadā. Rotenbergas, "loti modernas slimnīcas", direktors pelnīja daudz vairāk 6000 rubḷu gadā, vecākais ordinators - 4000 rubḷu gadā, jaunākais ordinators - arī 600 rubl̦u gadā. ${ }^{96}$

Krēpelīna ierašanās Krievijā nebija patīkama un viegla - problēmas ar iebraukšanu un muitu bija nogurdinošas. Vēlāk viņam vajadzēja detaḷās skaidrot, kādēl viņš par pārcelšanos iztērēja par 55 rubḷiem un 71 kapeiku vairāk, nekā piešksīra universitāte. Turpmākos četrarpus gadus bija jārisina organizatoriskas un valodas grūtības. Situācija ar valodu bija mulsinoša: ar pacientiem, kas pārsvarā runāja igauniski, un ar̄̄ ar krieviski un latviski runājošajiem profesors sarunājās tikai ar tulku palīdzību. Viņš nezināja nedz igauņu, nedz krievu valodu, ${ }^{97}$ lai gan savulaik, plānojot Dorpatas slimnīcas celtniecību, bija paredzēts, ka tās direktoram būs jāpārvalda

94 K. Maslov, V svete nezrimogo: zhizn' i sud'ba A. A. Krogiusa (Tallinn: Izdanie Tallinnskogo Universiteta, 2014), 72.

95 Holger Steinberg and Matthias C. Angermeyer, "Emil Kraepelin's years at Dorpat as professor of psychiatry in nineteenth-century Russia," History of Psychiatry 12 (2001): 297-327, https://doi.org/10.1177/0957154X0101204703

96 Jacqueline Lee Friedlander, Psychiatrists and Crisis in Russia, 1880-1917, 81.

97 Maike Rotzoll and Frank Grüner, "Emil Kraepelin and German psychiatry in multicultural Dorpat/Tartu, 1886-1891," Trames 20 (70/65), no. 4 (2016): 351-367, http:// www.kirj.ee/public/trames_pdf/2016/issue_4/trames-2016-4-351-367.pdf 
četras valodas - vācu, krievu, igauņu un latviešu. ${ }^{98}$ Tulku funkciju pildīja ordinatori, kas arī slikti saprata zemāko šksiru pacientu valodu (igauņu un latviešu). Iespējams, ka situāciju glāba zemākais personāls - slimnieku kopēji un uzraugi. ${ }^{99}$ Atbilstoši klīnikas pirmās desmitgades statistikas datiem 50 \% pacientu bija igauṇi (pārsvarā no lauku teritorijām), 30 \% bija vācieši (iespējams, daudziem vācu tautība pierakstīta prestiža dēḷ), 8 \% bija no Vidzemes guberņas, 3 \% bija ebreji un $2 \%$ - krievi. Kā redzams, šāds uzskaitījums neḷauj piln̄̄bā spriest par lingvistisko fonu pacientu vidū. ${ }^{100}$

Starp 1578 Dorpatas Universitātes studentiem no 1882. gada līdz 1886. gadam no Vidzemes guberņas bija 552, no Kurzemes - 335, no Igaunijas guberṇas - 145, vēl 523 studenti bija no dažādām citām Krievijas impērijas dal̦ām (pārsvarā Polijas) un 23 ārzemnieki. ${ }^{101}$ Rezultātā Leipcigas Universitātes medicīnas vēstures pētnieki secinājuši, ka "Krēpelīns bez lielām problēmām varēja sarunāties tikai ar kolēgiem - no 46 profesoriem 1889. gadā 40 bija no Vācijas" (pārējie četri bija krievi, viens no Vidzemes guberņas un viens bija "cits, bet ne igaunis"). Te varētu iebilst, ka vācbaltiešiem, kuri mācījās Dorpatas Universitātē, nevarēja būt lielu problēmu ar vācu valodas pārvaldīšanu.

Runājot par citiem studentiem un pasniedzējiem - tā kā sākotnēji mācību valoda bija vācu (Dorpatas Universitāte bija vienīgā vācu universitāte Krievijas impērijā), būtu dīvaini, ja studenti uz šo universitāti dotos studēt bez vācu valodas zināšanām. Bez svešvalodu zināšanām bija grūti kḷūt arī par universitātes profesoru. Jāpiebilst, ka vācbaltieši, atrodoties ārzemēs, mēdza sevi saukt par krieviem; ${ }^{102}$ ir viedoklis, ka Dorpatā vācbaltieši dzīvoja izolēti, nepiedalījās sabiedriskajā un kultūras dz̄ivē, pat tika diskriminēti. 103

98 Iukhan Luiga, Prizrenie dushevnobol'nykh v Pribaltiiskom krae, Istoriya prizrenia dushevnobol'nykh v ostzejskih guberniyah, 48.

99 Maike Rotzoll and Frank Grüner, "Emil Kraepelin and German psychiatry in multicultural Dorpat/Tartu, 1886-1891,” 355.

100 Ibid., 361.

101 Holger Steinberg and Matthias C. Angermeyer, "Emil Kraepelin's years at Dorpat as professor of psychiatry in nineteenth-century Russia," History of Psychiatry 12 (2001): 297-327, https://doi.org/10.1177/0957154X0101204703.

102 A. Blagoveshchenskii, Ostrov Ezel', gorod Arensburg i ikh dostoprimechatel'nosti, 145.

103 A. Hovsepjan, “Zhiznj' i rabota Emilj'a Krepelina”, Arm'anskij zhurnal psikhicheskogo zdorovj'a, № 4(1), 2013, 47-54. 
No 1884. gada Krievijas impērijā tika intensificēta rusifikācija un vācu valodas lietošana tika ierobežota. Cieta arī akadēmiskā brīvība, un vācu personāls sastapās ar lielām grūtībām - piemēram, kad Krēpelīns atteicās parakstīties ar krievu burtiem, viņš 1890. gada 28. maijā saņēma oficiālu Vidzemes guberņas gubernatora pavēli to darīt. Divus gadus vēlāk tika ievēlēts pirmais krievu rektors, un 1893. gadā universitāte oficiāli tika nosaukta par Jurjevas Universitāti.

Krēpelīna entuziasms (apvienot psihiatriju ar neiropsihologijiju) un darba spars drīz saruka, viņš jutās izolēts kā izsūtījumā un izmisīgi ilgojās pēc dzimtenes. Skolotājs Vundts vēstulēs viṇu uzmundrināja, rakstot, ka "arī Jūsu gadījumā Dorpatas Universitāte būs starpposms un Jūs drīz atgriez̄isieties pie mums". ${ }^{104}$ Iespējams, ar vārdu "arī Jūsu gadījumā” bija domāts Eminghauss. Tomēr tas netraucēja Krēpelīnam dibināt Dorpatas Psiholoǵisko biedrību (1887), atklāt jaunu psiholoǵisko laboratoriju (1888) un veikt dažādus pētījumus psihofizioloǵijas un psihofarmakoloǵijas jomā. Piemēram, viņš pētīja vingrinājumu un noguruma efektu uz psihiskajām funkcijām, hioscīna efektu uz psihiski slimajiem. Sākot no 1887. gada, Krēpelīnu gimene sāka doties garos atvaļinājuma ceḷojumos - pārsvarā vasarā, ko viņi uzskatīja par kompensāciju savām ciešanām Dorpatā pārējos mēnešos. Šie atelpas brīži bija iespējami tikai pēc smagām cīnām ar Krievijas birokrātiem.

Tā kā lielākā daḷa viņa pacientu nerunāja vāciski, Krēpelīns bija spiests izmantot izmeklēšanas metodi, kas nav saistīta ar valodu - novērošanu, un pievērsties rūpīgai informācijas ievākšanai slimības vēsturēs un statistikai. Krēpelīns tika raksturots kā intraverts, kas labāk pievērsās pacientu novērošanai un viņu slimības vēsturu pētǐšanai nekā darbam pie slimnieka gultas.

Piedāvājumu ieņemt jaunu vietu Heidelbergas Universitātē Krēpelīns pieñēma vienā mirklī - viṇa prasība pēc atvalıināšanas no Krievijas cara dienesta ir datēta ar 1890. gada 9. novembri - to pašu dienu, kad viņš saņēma oficiālu nosūtījumu uz Heidelbergu. Tiesa, Krievijas birokrāti atkal lika viņam šķēršļus - izglītības ministrs lika viņam gaidīt līdz pat 1891. gada februārim (demisija tika pieņemta ar 1891. gada 1. aprīli). Paskaidrojot savas aiziešanas iemeslu universitātei, Krēpelīns skaidri

104 Holger Steinberg and Matthias C. Angermeyer, “Emil Kraepelin's years at Dorpat as professor of psychiatry in nineteenth-century Russia," 297-327. 
norādīja uz rusifikāciju: "Es nekā nezinu par Jurjevas Universitāti, un man ar to nav nekā kopīga." 105

Pēdējā ziema Krievijā un jo īpaši cel̦ojums atpakal̦ uz Vāciju bija smags - ǵimene brauca ar vilcienu, šì garā cel̦ojuma laikā saslima un nomira viṇu dēls. Gadu iepriekš Krēpelīni jau zaudēja jaunāko meitu. Tomēr tikšanās ar dzimteni ātri dziedēja vecāku brūces. ${ }^{106}$

Divdesmitajā gadsimtā daudzi kritizēja Krēpelīna neitrālo attieksmi pret deǵenerācijas / rasu psihiatrijas teoriju, tajā saskatot profašisma noskaņas: dažas psihisko traucējumu izpausmes viņš skaidroja ar atgriešanos iepriekšējos evolūcijas posmos; teoretizēja par ebreju ǵenētisko noslieci uz psihiskajām slimībām un vēl 1880. gadā savā grāmatā "Par sodu atcelšanu"107 izteica ideju par centralizētu noziegumu prevenciju, iedarbojoties uz atlasāmām predisponētām personām, kuras no sabiedrības būtu profilaktiski jāizolē vai jāpakḷauj individualizētam korekcijas plānam - turklāt jāvadās no t. s. sociālās bīstamības principa. ${ }^{108}$

Viens no viņa līdzstrādniekiem un Rasu higiēnas biedrības (Society of Racial Hygiene) dibinātājiem (1905), Ernsts Rtidins (Ernst Rtidin, 18741952), kas no 1907. gada strādāja Krēpelīna klīnikā Minhenē, 20. gadsimta 30. gados kḷuva par galveno personu, kas izstrādāja psihiski slimo iznīcināšanas likumus. ${ }^{109}$ Pēc Pirmā pasaules kara, kad Eiropas sabiedrība un ārsti saskārās ar līdz šim nepieredzētu psihisko traucējumu epidēmiju, t. s. shellshock sindromu (mūsdienās - akūta stresa reakcija), vācu psihiatriem bija īpaša nostāja diagnostikā. Viṇi uzskatīja, ka shell-schock sindroma slimnieki īstenībā bija konstitucionāli predisponēti deǵenerācijai, t. s. nācijas parazīti (Volkskörper, sk. Krēpelīna psihopātu klasifikāciju viņa mācību grāmatas septītajā izdevumā), kam nav tiesību uz dzīvību; viṇiem atṇēma

105 Holger Steinberg and Matthias C. Angermeyer, "Emil Kraepelin's years at Dorpat as professor of psychiatry in nineteenth-century Russia," 317.

106 Ibid., 297-327.

107 Emil Kraepelin, Die Abschaffung des Strafmasses: Ein Vorschlag zur Reform der heutigen Strafrechtspflege (Stuttgart: Enke, 1880).

108 Mūsdienās ar sociālo bīstamību saprot risku, ka slimnieks, kurš saṇem piespiedu ārstēšanu, veiks pārkāpumu vai noziedzīgu nodarījumu atkārtoti (de jure to nosaka tiesa, nevis ārsti). Savukārt profilaktiska nozīme tiek piešķirta darbam ar pusaudžiem ar emocionāliem un uzvedības traucējumiem un augstu delinkvences un marginalizācijas risku.

109 Paul Hoff, “The Kraepelinian tradition," Dialogues Clin Neurosci 17, no. 1 (2015): 31-41, https:/www.ncbi.nlm.nih.gov/pmc/articles/PMC4421898/ 
pensiju un liedza medicīnisko palīizzību. ${ }^{110}$ Krēpelīns par viņiem rakstīja, ka "mēs, alienisti, 111 esam gatavi ierobežot dāsnu pabalstu piešķiršanu, kas varētu novest pie drausmīgām sekām - demobilizācijas veselības stāvokḷa dēl un saslimstības pieauguma". Pēc viņa domām, situāciju pasliktināja sabiedrības vainas sajūta "šksietami smagi slimo trīcinātāju (war-shakers, Kriegszilterer) priekšā, kas pievērš sev lielu uzmanību ielu krustojumos, un viņiem tiek dāsni ziedots". ${ }^{112}$ Pirmā pasaules kara oponentus (pacifistus) un sociālistus Krēpelīns uzskatīja par psihiski slimiem. ${ }^{113}$

\section{Emīls Krēpelīns kā klīnikas vadītājs}

1885. gadā klīnikas budžets bija 15630 rubḷi, savukārt 1890. gadā jau 32016 rubḷi. Lielāko daḷu veidoja pacientu maksa par ārstēšanu, kas tobrīd skaitījās diezgan augsta. Papildu ienākumus veidoja ziedojumi no muižniekiem un ikgadēja valdības subsīdija 2000 rubḷu apmērā. Tomēr 1887. gada 12. martā Krēpelīns rakstīja universitātes administrācijai un lūdza aţ̦aut paaugstināt pacienta iemaksu par ārstēšanu klīnikas bēdīgās finansiālās situācijas dēḷ. Klīnika bija būvēta 50 pacientiem, un vēl Eminghauss sastapās ar stacionāra pārpildīšanas problēmu, savukārt, kad tajā ieradās Krēpelīns, tur ārstējās 66 personas. Lai arī gultu skaitu palielināja par 10 vienībām, pārslodze arvien pieauga un profesors Vladimirs Čižs pat atdeva savu dzīvokli pacientu palātas izveidei. ${ }^{114}$ Salīdzinājumam - slavenais zviedru psihiatrs Veterstrands (Wetterstrand), kurš vadīja Konradsbergu, Stokholmas psihiatrisko slimnīcu, gaudās par pārslodzi, kad viņa iestādē 265 slimnieku vietā bija par trijiem vairāk.

Psihiatriskās klīnikas no slimnīcām un vājprātīgo namiem atšksīrās ar pedagoǵisko un pētniecisko darbu, kas tajās regulāri notika. Studentu apmācībai un slimnieku demonstrācijai bija nepieciešami nesen saslimušie,

110 Marina Loseviča, Evija Siliṇa un Inta Rozentāle, "Histērija mūsdienās," Latvijas Arsts (2018 augusts): 6-19.

111 Tā Krēpelīna dzīves laikā dēvēja psihiatrus.

112 Marc-Antoine Crocq, "From shell shock and war neurosis to posttraumatic stress disorder: a history of psychotraumatology," Dialogues Clin Neurosci 2, no. 1 (March 2000): 47-55, https://www.ncbi.nlm.nih.gov/pmc/articles/PMC3181586/

113 Andreas Ebert and Karl-Jürgen Bär, "Emil Kraepelin: A pioneer of scientific understanding of psychiatry and psychopharmacology," Indian Journal of Psychiatry 52, no. 2 (2010): 191-192, doi:10.4103/0019-5545.64591.

114 Holger Steinberg and Matthias C. Angermeyer, "Emil Kraepelin's years at Dorpat as professor of psychiatry in nineteenth-century Russia," 297-327. 
nevis hroniski slimie pacienti. ${ }^{115}$ Sākotnēji slimnieku demonstrācija notika klīnikas ēdamtelpā, vēlāk Krēpelīns šim nolūkam ieguva kādu ērtāku istabu pilsētā, kas bija vieglāk pieejama studentiem. Katru semestri viņš lasīja lekcijas klīniskajā psihiatrijā un centās šīs lekcijas padarīt iespējami interesantas, demonstrējot slimniekus (nav skaidrs, vai tie bija tikai vāciski runājošie slimnieki). ${ }^{116}$

Attiecībā uz klīnisko darbu Krēpelīns bija hidroterapijas entuziasts. Viņš slimnieku atrašanos mēreni siltā vannā (zem cieša vāka vai uzraugu turēts; ar vai bez aukstiem apliekamajiem uz galvas) pagarināja līdz pat vairākām nedēḷām un ļoti lepojās ar sasniegumiem (mūsdienu cilvēktiesību aktīvisti to varētu uzskatīt par visnotaļ nežēlīgu ierobežošanas veidu).

Viņš ieviesa klīnikā hipnoterapiju ("hipnotismu”) un plaši izmantoja to neirotiska spektra traucējumu ārstēšanā. Kā vēlākais atturības propagandists (iespējams, to sekmēja viņa tēva alkoholisms), ārstējot trauksmi, uzmācību, agorafobiju un melanholiju, ${ }^{117} \mathrm{Krēpelīns} \mathrm{ieteica} \mathrm{mazas} \mathrm{alkohola}$ devas, kas, viņaprāt, padarīja ārstēšanu vieglāku. Vācu psihiatriem bija tipiski ieteikt alu bezmiega ārstēšanai. Interesanti, ka Krēpelīns zināja un izmantoja placebo efektu (kuru it kā aprakstīja vēlāk).

1907. gadā Krēpelīna students Alberts Bērs nodibināja Strenču Psihiatrisko slimnīcu un kļuva par tās direktoru. Bija doma, ka Strenču slimnīca uzņems lielu daļu Dorpatas un Rīgas slimnieku, mazinot to slogu, bet tam nebija pastāvīga efekta, un Dorpatas klīnikai auga parādi.

Nacistu okupācijas laikā slavenais vācu psihiatrs Kurts Šnaiders (Kurt Schneider, 1887-1967) strādāja Dorpatā kā vērmahta kara ķirurgs. ${ }^{118}$ Viṇš atrada vairākas slimības vēstures, ko sarakstījis Krēpelīns. Mūsdienās vairākas no tām atrodas Igaunijas Nacionālajā arhīvā. ${ }^{119}$ Klīnikas arhīvs

115 Maike Rotzoll and Frank Grüner, "Emil Kraepelin and German psychiatry in multicultural Dorpat/Tartu, 1886-1891,” 354.

116 Ibid., 355.

117 Mūsdienu izpratnē - dažādus trauksmes veidus līdz ar pazeminātu noskaņojumu.

118 Vēlāk K. Šnaiders psihiatrijas vēsturē iegāja ar skaidru un konstruktīvu šizofrēnijas produktīvo simptomu definīciju (1938). 1946. gadā K. Šnaiders denacifikācijas programmas gaitā nomainīja Heidelbergas klīnikas vadītāju. No 1933. gada līdz 1945. gadam klīniku vadīja viņa vārdabrālis Karls Šnaiders (1891-1946), psihiski slimo sterilizācijas un iznīcināšanas programmas vecākais pētnieks. Sk.: M. Rotzoll, G. Hohendorf, Krankenmord im Dienst des Fortschritts? Der Nervenarzt (2012) 83: 311. https://doi.org/10.1007/s00115-011-3392-6.

119 Holger Steinberg and Matthias C. Angermeyer, "Emil Kraepelin's years at Dorpat as professor of psychiatry in nineteenth-century Russia," 297-327. 
glabā diezgan daudz slimības vēsturu no Krēpelīna un pat Eminghausa laikiem (ar īsiem Krēpelīna ierakstiem). ${ }^{120}$ Slimniekam iestājoties, tika aizpildīta anketa - iespēju robežās to darīja slimnieks pats. Līdzīgas anketas (ar anamnēzes datiem, informāciju par saslimšanas apstākḷiem) bija arī citās Krievijas psihiatriskajās iestādēs, bet Dorpatas klīnikā tās bija bilingvālas.

\section{Krēpelīna nosūtījumi uz Aleksandra Augstumiem}

Strādājot par Vidzemes guberņas ārstu, Krēpelīns pabeidza savas slavenās mācību grāmatas otro un trešo sējumu. ${ }^{121}$ Viṇa pirmā īsā psihiatrijas mācību grāmata "Compendium der Psychiatrie" bija publicēta vāciski 1883. gadā, bet jau 1891. gadā tika iztulkota krieviski. ${ }^{122}$ Interesanti, ka Birk Engmann et al., analizējot Krēpelīna gadus Dorpatā un viņa ietekmi uz Krievijas un padomju psihiatriju, konstatēja, ka visi darbi, kas bija pārtulkoti krieviski, tapa pēc Dorpatas perioda, tādēḷ lielu ietekmi uz tā laika Krievijas psihiatriem un neirologiem atstāt nespēja. Secināts - tā kā neviens no Krēpelīna tā laika studentiem neieguva zinātnisko grādu, viṇi nevarēja Krēpelīna idejas nodot tālāk uz Krieviju. ${ }^{123}$ Mūsuprāt, pieņemt, ka toreiz krievu izcelsmes ārsti zināja tikai krievu valodu, ir nepamatoti.

Tik tiešām, strādājot Dorpatā, Krēpelīna uzskati un sistēma daudz neatšksīrās no viņa priekšteču uzskatiem. Tikai vēlāk, strādājot vācu augstskolās, iegūstot plašu klīnisko novērojumu bāzi, 19. gadsimta 90. gados viņa teorētiskie uzskati mainījās un savā mācību grāmatā (1896. gadā iznāca tās piektais izdevums) viņš piedāvāja jaunu psihisko slimību klasifikāciju. ${ }^{124}$

${ }^{120}$ Maike Rotzoll and Frank Grüner, "Emil Kraepelin and German psychiatry in multicultural Dorpat/Tartu, 1886-1891,” 361.

121 Andres Lehtmets and Veiko Vasar, "The Past and the Present of Estonian Psychiatry," Nordic Journal of Psychiatry 64, no. 5 (2010): 350-352. doi: 10.3109/08039488.2010.520208.

122 Maike Rotzoll and Frank Grüner, "Emil Kraepelin and German psychiatry in multicultural Dorpat/Tartu, 1886-1891," 363.

123 Birk Engmann and Holger Steinberg, "Die Dorpater Zeit von Emil Kraepelin Hinterließ dieser Aufenthalt Spuren in der russischen und sowjetischen Psychiatrie?,' Fortschritte der Neurologie. Psychiatrie 85 no. 11 (November 2017): 675-682.

124 Alexander Friedmann and Kenneth Thau, Leitfaden der Psychiatrie (Wien, München, Basel: Vlg. Wilhelm Maudrich, 1987), 242-243. 
Ir piln̄̄gi saprotami, ka, strādājot par Vidzemes guberņas ārstu, ${ }^{125}$ Krēpelīns tikai veidojās kā klīnicists un zinātnieks un viņam nevarēja būt lielu revolucionāru sasniegumu. Tikpat saprotami, ka jauns ārsts, aizrāvies ar eksperimentiem un moderno ārstēšanas metožu ieviešanu, strādājot maksas klīnikā, Aleksandra Augstumu vājprātīgo nodaļu uzskata par pansionātu hroniski slimajiem un sūta tur smagi slimus vai neārstējamus slimniekus.

Slimniekiem, ko no mūsdienu Igaunijas teritorijas sūtīja uz Aleksandra Augstumiem, bija nepieciešama gan ārstēšana psihiatriskajā iestādē, gan tikai sociālā aprūpe nabagmājā - piemēram, kāda igaunu apriņ̧̧a administrācija apraksta tur dzīvojošās sešas vājprātīgās (ieskaitot kādu “A. L. - pastāvīgi uzbudinātu un agresīvu”) un daudzus seniorus, kuriem nepieciešams atbalsts un rūpes, bet tiesību uz bezmaksas aprūpi nabagmājā viņiem nav. ${ }^{126}$

Kāds igauņu novads lūdza zemnieku lietu komisāru Aleksandra Augstumos uzņemt pacientu, kurš ilgstoši ārstējās Krēpelīna klīnikā, kurai novads ziedoja 100 rubļu. Slimnieks tika atzīts par nedziedināmu un sūtīts mājās aptuveni pirms gada: "Vīrietis vidējos gados un spēku briedumā perina dažādas nejēdzības (zatevaiet raznye gluposti), pie kam viņu nenotur ne apsargi, nedz arī važas - divus pārus važu viņš jau iznīcināja." 127 Jādomā, ka pacientam bija ilgstoša (nezināmas etiologijas) psihoze ar smagu psihomotoru uzbudinājumu.

Līdzīga situācija bija arī 20. gadsimta sākumā: "Purmaņu pagastā128 šobrīd daudz vājprātīgo tiek uzturēts sabiedrības spēkiem, kas ir ārkārtīgi grūti [..], jo pagastā trūkst telpu vājprātīgo uzturēšanai [..]."129 Tādējādi Aleksandra Augstumi arvien vairāk pārvērtās par patversmi nedziedināmi, hroniski psihiski slimajiem no visas Vidzemes guberņas.

${ }^{125}$ Isidorus Brennsohn, Die Aerzte Livlands von den ältesten Zeiten bis zur Gegenwart: Ein Biographisches Lexikon Nebst Einer Historischen Einleitung Über Das Medizinalwesen (Mitau: J. F. Steffenhagen und Sohn, 1905), 248.

126 LNA LVVA, 30-1-3572, 1.

127 Ibid., 60.

128 Purmaņu pagasts atradās Dorpatas (Jurjevas, mūsdienu Tartu) apriņķ̄i.

129 LNA LVVA, 30-1-4017, 111. Purmales apriņ̧̧a izredzēto personu sēdes protokols 1905. gada 7. aprīlī. 


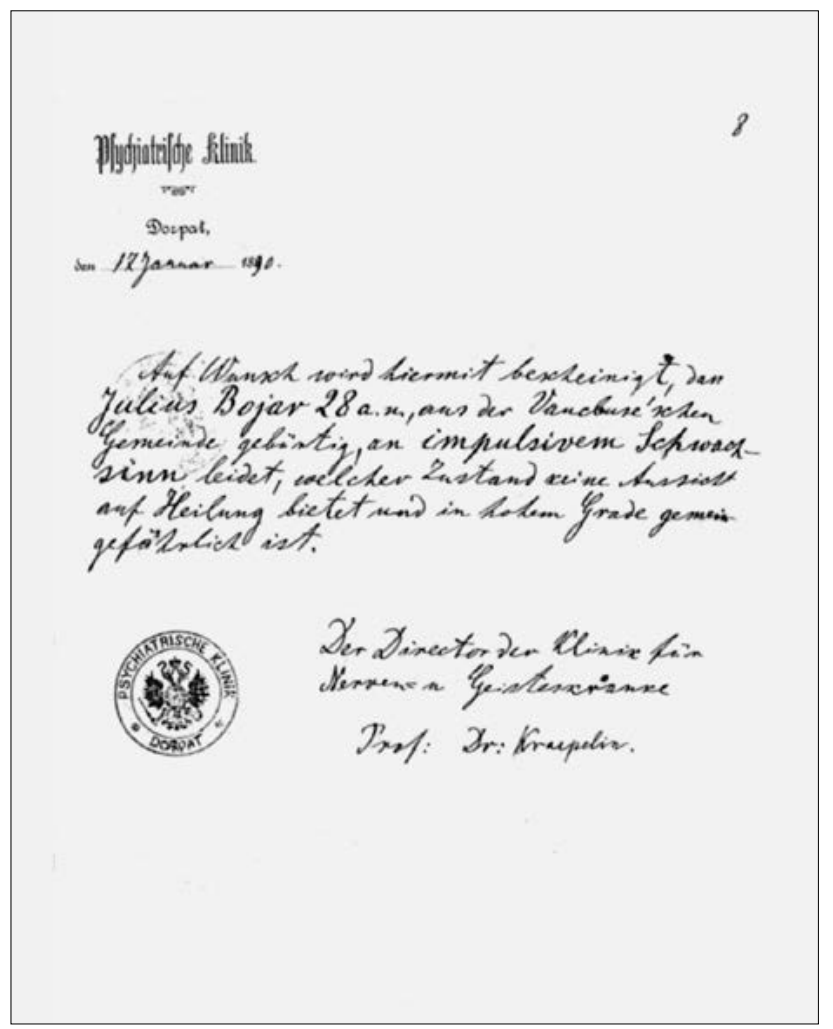

Pacienta J. Bojāra nosūtījums no Dorpatas Universitātes Nervu un psihisko slimību klīnikas uz Aleksandra Augstumu vājprātīgo namu, ko parakstījis profesors E. Krēpelīns vācu valodā, 1890. gads. Tobrīd vēl nebija izdota gubernatora pavēle profesoram parakstîties krieviski (avots: LNA LVVA, 30-1-3539, 8)

Arhīvos atrodamas ziņas par kāda Jūlija Bojāra (Julius Bojar), 28 gadus veca vīrieša, uzņemšanu Aleksandra Augstumos. Vīrietis cieta no "impulsu ārprāta" (impulsive Schwachsinn), bija nedziedināms un sabiedrībai bīstams. 1890. gada 17. janvārī lūgumu viņu hospitalizēt Aleksandra Augstumos parakstīja profesors Krēpelīns. ${ }^{130}$

130 LNA LVVA, 30-1-3572, 8. 


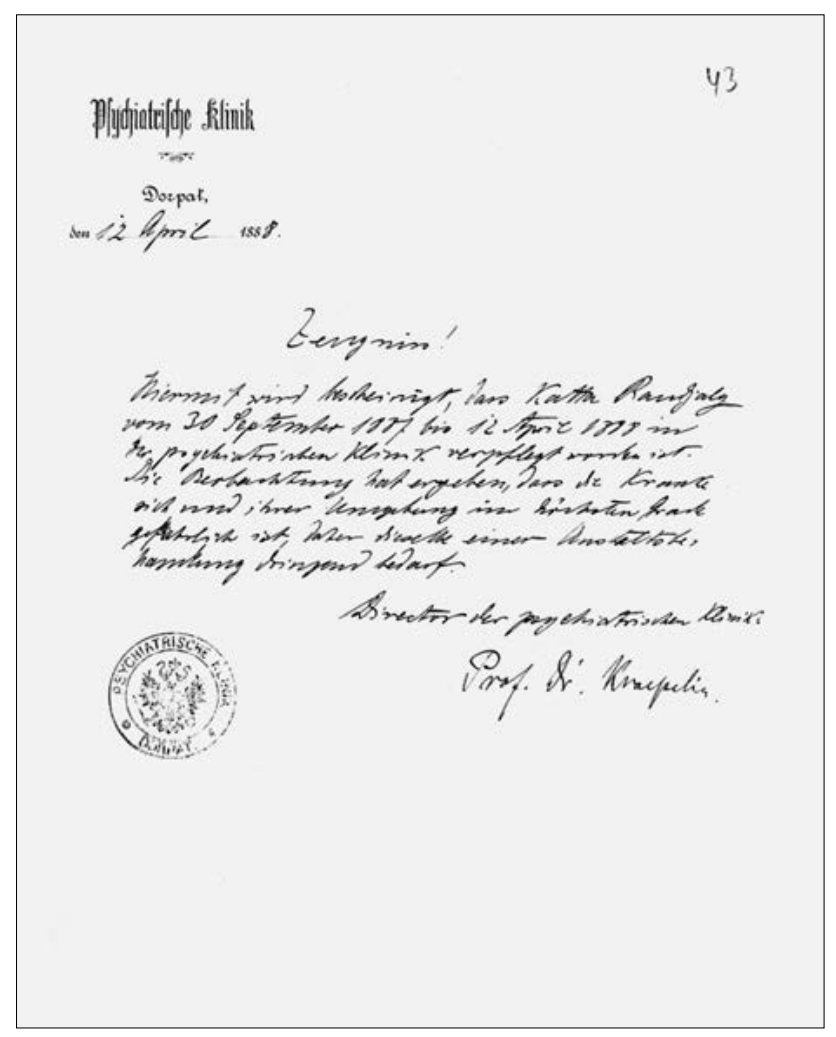

Profesora E. Krēpelīna vāciski sastādīts atzinums par Kattu Raudialg - pacienti, kura no Dorpatas Nervu un psihisko slimību klīnikas tika pārvesta uz Aleksandra Augstumiem, 1888. gads (avots: LNA LVVA, 30-1-3539, 43)

Cits līdzīgs atzinums, ko Dorpatas policijai sastādīja Krēpelīns, bija par kādu zaldāta sievu (soldatka) Kattu Raudialg ar diagnozi "Paranoia? Insania circulatoria". ${ }^{131}$ Viña bija 35 gadus veca strādniece no Dorpatas, precējusies, bez izglītības, igauniete, kura atradās klīnikā no 1887. gada 30. septembra līdz 1888. gada 12. aprīlim. Profesors viņu atzina par sev un apkārtējiem ārkārtīgi bīstamu, norādot nepieciešamību atrasties trakonamā. ${ }^{132}$ Sieviete tika nosūtīta uz Aleksandra Augstumiem.

131 Tulkojumā: Murgi? Cirkulārs ārprāts. (Varētu atbilst epizodiskas norises šizofrēnijai mūsdienu izpratnē.)

132 LNA LVVA, 30-1-3539, 42. 


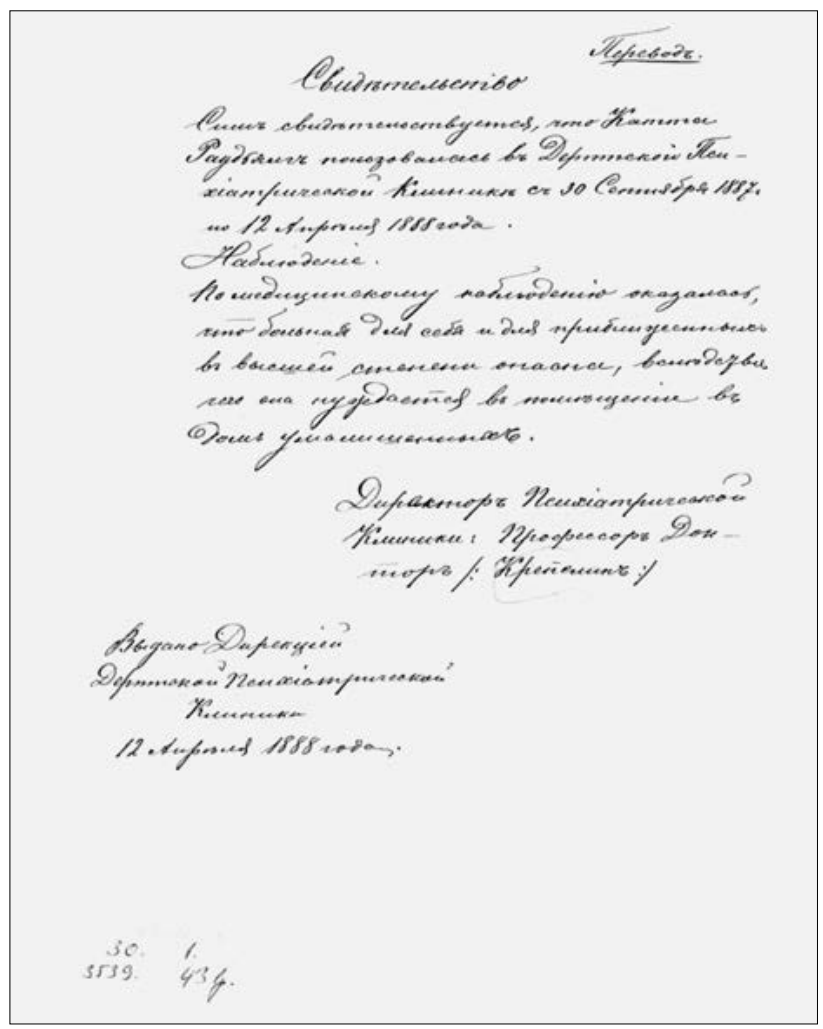

Profesora E. Krēpelīna sastādītā atzinuma tulkojums krieviski par Kattu Raudialg - pacienti, kura tika pārvesta no Dorpatas Nervu un psihisko slimību klīnikas, 1888. gads (avots: LNA LVVA, 30-1-3539, 43. 1p. o. p.)

Slimības vēsturē īsi un konstruktīvi aprakstīta slimības norise, kas atbilst mūsdienu epikrīzes sākumdaḷai:

"Nelabvēlīgas iedzimtības nav, pirms astoņiem gadiem jau reiz bija sajukusi prātā [pēcdzemdību psihoze? - autoru piezīme]. Ir divi veseli bērni - 6 un 8 gadi. Trešais bērns nomira 1887. gada augustā nepilna gada vecumā. Kopš viņa nāves dienas izmain̄ijās psihiskais stāvoklis: bieži apmeklēja kapus, visiem stāstīja, ka ir liela grēciniece, ka Dievs viṇu nemīl. Augām dienām staigāja apkārt, četras nedēḷas nav bijusi apetīte un miegs. Trīs dienas acu priekšā redzēja gaismu, domāja, ka tas ir Dievs. 
Tādā stāvoklī pēc Dorpatas apriņķa militārā priekšnieka rīkojuma uzñemta klīnikā. Visu oktobri nerunīga, ir bezmiegs, sevi uzskata par briesmīgu grēcinieci, kura nav pelnījusi Dieva žēlastību; ir redzes, ožas, dzirdes ilūzijas, personālu uzskata par gariem vai rēgiem. Galvas forma - pareiza, perifēriskie nervu, plaušu, sirds un artēriju izmeklējumi - normā, vēders nesāpīgs, urīnceḷi un dzimumorgāni bez patologiijas, izdalīšanas funkcijas kārtībā, apetīte laba.

Uz rokas virs labās plaukstas locītavas brūce [pēc paškaitējuma? aut.]. Sejas izteiksme dusmīga, uzvedība nemierīga, kustību nervu kairinājums [domājams, psihomotorais uzbudinājums - aut.]. Runā tikai par saviem aplamiem priekšstatiem, par savu grēcīgumu.

30.04. Brūce sadzija, sejas izteiksme mīlīga, kairināmība pārgāja, augām dienām sēž pie loga un izsaka visdažādākās aplamas domas.

15.05. Kairināmība. Apetīte un izdalīšanas funkcija normā.

25.07. Garastāvoklis jautrs, runā bez apstājas nesaistītas lietas. Vietā orientēta pareizi - saprot, ka atrodas slimnīcā. Brīžiem parādās aplami priekšstati - piem., ārstu un feldšeru uzskata par saviem līgavaiņiem. Uz jautājumu, vai atceras, ka sevi uzskatīja par policmeistera līgavaini, atbild apstiprinoši un piebilst, ka tas tā ir jau ilgāku laiku."'133

Lai arī prognostiskās pazīmes - sieviešu dzimums, epizodiska slimības norise (iepriekš jau pārciests slimības uzliesmojums, no kura viņa bija atvesel̦ojusies), straujš slimības sākums, ko izprovocēja smaga psihiska trauma, - bija labas, Krēpelīns zaudēja entuziasmu pacientes ārstēšanā. Domājams, ka cēlonis tam bija ilgstošā psihozes norise. Diemžēl nav norādīta saņemtā ārstēšana un slimnieces pārvešanas iemesli (bīstamība sev un apkārtējiem nav aprakstīta).

LNA LVVA, 30-1-3539, 104.-105. lp. 
Дерптская Городская Больница.

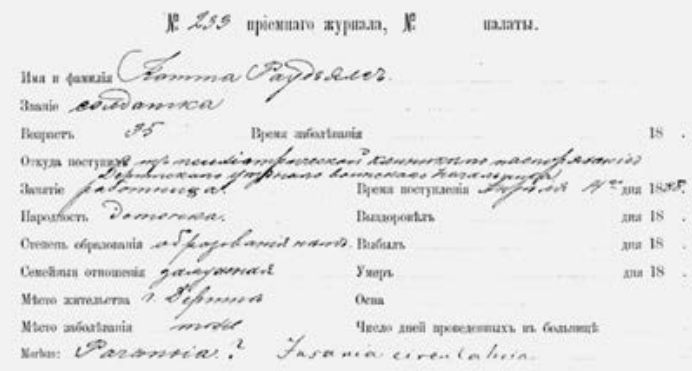

\begin{tabular}{|c|c|c|c|c|}
\hline Menis & Histeria et decersus warhe & Rosela ixema. & Renenta eaters. & Disits. \\
\hline
\end{tabular}

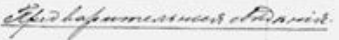

Hes

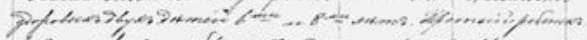

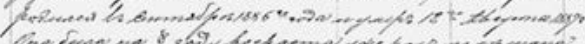

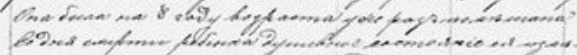

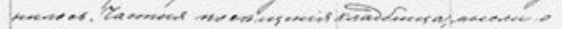

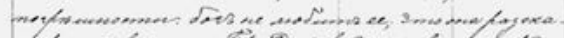

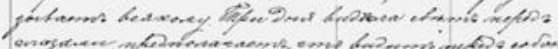

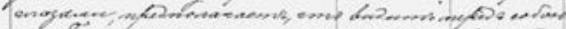

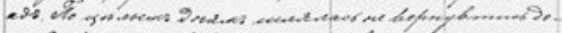

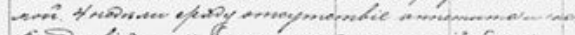

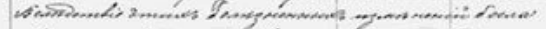

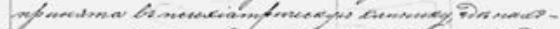

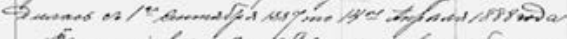

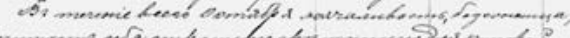

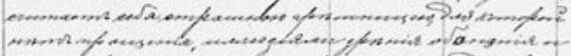

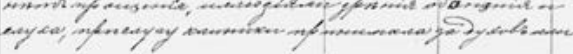

(1)

No Dorpatas Nervu un psihisko slimību klīnikas pārvestās pacientes Kattu Raudialg slimības vēstures kopijas

1. lpp. krievu valodā, 1888. gads

(avots: LNA LVVA, 30-1-3539, 104-105) 


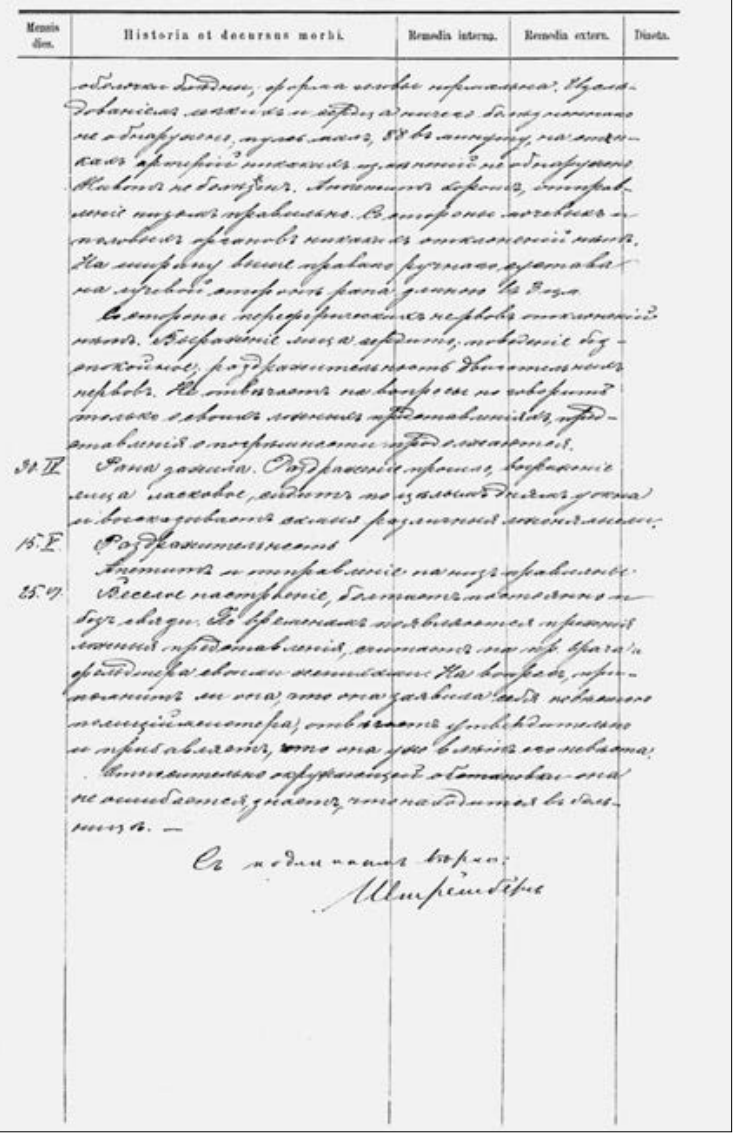

No Dorpatas Nervu un psihisko slimību klīnikas pārvestās pacientes Kattu Raudialg slimības vēstures kopijas

2. lpp. krievu valodā, 1888. gads (avots: LNA LVVA, 30-1-3539, 104-105) 


\section{Krēpelīna nozīme psihiatrijas nozarē}

Ar Krēpelīna vārdu psihiatrijā tiek saistīta virkne jaunievedumu.

1. Rūpīga, uzmanīga, liela mēroga pētījumu veikšana, ar vienotu metodologiju un viņa izstrādātām klīniskajām skalām.

2. Nesteidzīga faktu un fenomenu aprakstīšana, ar ilgstošu longitudinālo novērošanas periodu.

3. Atvērtība kritikai un gatavība radikāli mainīt savus uzskatus.

4. Krēpelīns izdalīja divu veidu endogēnās psihozes: šizofrēniju (kā neizbēgami dementizējošu smadzeņu saslimšanu) un bipolāri afektīvos traucējumus (ar epizodisku norisi un labu prognozi). Dementia praecox jeb šizofrēnijas koncepciju Krēpelīns izstrādāja 1899. gadā, savukārt E. Bleilers (Bleuler) to izmantoja un attīstīja 1911. gadā (vēlāk šizofrēnija tiks saukta par Bleilera slimību). ${ }^{134} \mathrm{H}$. Budula mācību grāmatā latviešu valodā jau tiek izmantots termins "šizofrēnija”. ${ }^{135}$ Mūsdienās šis psihožu iedalījums vēl joprojām pastāv, lai gan genētiski pētījumi sniedz arvien vairāk pierādījumu, ka endogēnām psihozēm ir vienota ǵenētiska "augsne". Japānā 2002. gadā, vadoties pēc šizofrēnijas slimnieku ǵimeņu prasībām (attālinoties no Krēpelīna tradīcijas un cīṇā ar stigmatizāciju), vārds "šizofrēnija" tika veiksmīgi nomainīts pret "nozīmīguma disregulācijas sindromu" (salience dysregulation syndrome). ${ }^{136}$

5. Krēpelīns radīja jaunu klasifikācijas sistēmu, ko vēlāk ar sajūsmu uztvēra kolēǵu sabiedrība. Terminoloǵijas un klasifikācijas neskaidrības (mūsdienās teiktu - diagnostisko kritēriju trūkums) bija tā laika psihiatrijas bieds. Traucējumus klasificēja pēc to ārējām pazīmēm (to var salīdzināt ar iekšējo slimību klasifikāciju pēc klepus vai tūskas parādīšanās, kas ir nolemta neveiksmei, jo, piemēram, šizofrēnijas gadījumā ir iespējama pilnīgi visa psihopatoloǵija), vienīgais izṇēmums bija progresējošā paralīze. Ideju, ka slimības etioloǵija, norise, iznākums un patoanatomija veido nozoloǵiju, 19. gadsimta 80. gados izvirzīja Kālbaums (Karl Ludwig

134 Andreas Ebert and Karl-Jürgen Bär, "Emil Kraepelin: A pioneer of scientific understanding of psychiatry and psychopharmacology," Indian Journal of Psychiatry 52(2): 191-192. doi:10.4103/0019-5545.64591; http://www.indianjpsychiatry.org/temp/ IndianJPsychiatry522191-4390705_121147.pdf

135 Hermanis Buduls, Psihiatrija: specialā daļa (Rīga: Valters un Rapa, 1929).

136 Jim van Os, “'Salience syndrome' replaces 'schizophrenia' in DSM-V and ICD-11: psychiatry's evidence-based entry into the 21st century?" Acta Psychiatrica Scandinavica 120, no. 5 (November 2009): 363-372, doi:10.1111/j.1600-0447.2009.01456.x. 
Kahlbaum, 1828-1899), savukārt 1896. gadā to izmantoja Krēpelīns savā psihiatrijas mācību grāmatas piektajā izdevumā. Krēpelīns slimības sāka klasificēt pēc to norises un iznākuma (mūsdienās teiktu - pēc maksimāli bioloǵiskām pazīmēm), par slimnieka konsultācijas galējo mērķi izvirzot tieši prognozi.

Divdesmitā gadsimta pirmajā pusē psihiatru vidū sākās, no vienas puses, intensīva Krēpelīna ideju kritika, no otras, - viņa ideju attīstība (līdzīgu dinamiku piedzīvo daudzu zinātnieku mācības - slaveno Freida teoriju Eiropā sagaidīja iznīcinoša kritika, ar retiem izṇēmumiem - piemēram, E. Bleileru un V. Serbski). ${ }^{137}$ Sevišksi lielu protestu izraisīja slimību klasifikācija pēc to iznākuma - jo pats Krēpelīns piel̦āva izṇēmumu no likumsakarībām: proti, ka 8-13 \% dementia praecox pacientu var atveseļoties. ${ }^{138}$ Tātad slimība, kuras galvenā pazīme ir ātra dementizācija, var beigties visnotaḷ labvēlīgi, saglabājot psihi. 1908. gadā Berlīnē Vācu psihiatru biedrības sapulcē psihiatrs Pepenheims (Pappenheim) paziņoja, ka liela daļa slimnieku, kam Krēpelīns Heidelbergas klīnikā noteica dementia praecox diagnozi, izveseļojās. Toreiz psihiatri ar vārdu "plānprātība" saprata daudz plašāku fenomenu nekā tikai noturīgu un neatgriezenisku kognitīvo funkciju mazināšanos, kā tas ir mūsdienās. Ar to saprata stāvokli, kam bija raksturīgs bezpalīdzīgums, nesakarīga domāšana, nesaprātīga rīcība un uzmanības vājums. ${ }^{139}$

Kopumā vairums psihiatru Krēpelīna klasifikāciju uztvēra pozitīvi: no samudžinājuma pēkšņi tika radīta loğiska, vienkārša, uz empīriskām zināšanām pamatota sistēma. Vēlāk vienbalsīgi tika akceptēta Karla Jaspera vispārējās psihopatologijas grāmata (aizstāvēta disertācijas veidā 1913. gadā), kas psihiatriem sniedza sava veida esperanto (vienotas ārstu profesionālās valodas) zināšanas. Jāatz̄ist, ka līdzīgu - nozolog̣isku - slimību klasifikāciju piedāvāja arī Sergejs Korsakovs (1854-1900), Maskavas Psihiatriskās

${ }^{137}$ Iu. Savenko, "Nasledie Krepelina i Freida v sovremennoi psikhiatrii: priobreteniia I izderzhki," Nezavisimyi Psikhiatricheskii Zhurnal 2 (2006): 7-10, http://npar.ru/wpcontent/uploads/2016/02/№2_2006.pdf

138 Mūsdienās to skaidro ar neiroplasticitāti - smadzeņu spēju atjaunoties pēc pārciestās psihozes (sk.: Guo, S. Palaniyappan, L. Liddle, P. F. Feng, J. "Dynamic cerebral reorganization in the pathophysiology of schizophrenia: a MRI-derived cortical thickness study," Psychological Medicine, 46 (10): 2201-2214.

139 Iurii Kannabikh, Istoriia psikhiatrii (Moskva: Iurait, 2019), 320. 
skolas pamatlicējs (pēc padomju psihiatra Fjodora Slučevska domām, viṇa darbi kḷuva par Krēpelīna klasifikācijas pamatu). ${ }^{140}$

6. Psiholoǵiskā eksperimenta un psihofarmakoloǵisko pētījumu ieviešana klīniskajā praksē - piemēram, psihiatri, veicot kognitīvo funkciju pārbaudi, joprojām izmanto "skaitī̌sanu pēc Krēpelīna". Te jāmin Aleksandra Augstumu ārsta (1894-1896) Ernsta Augusta Emīla Sokolovska ${ }^{141}$ disertācija "Par reflekskairinātājiem" (1898), kurā tiek pētīta uzmanības un regulētājfunkciju (executive functions) darbība. Sokolovskis strādāja par prof. Čiža asistentu un Krēpelīnu sauca par savu skolotāju.

7. Ar Krēpelīnu saistās salīdzinošās transkulturālas psihiatrijas sākums (idejas apstiprinājās, analizējot Ufas zemstes psihiatrijas klīnikas datus par 1901. gadu, un attīstījās, cel̦ojot uz Javu, Indiju, Ziemel̦ameriku). Te jāatceras latviešu profesora H. Budula disertācija "Par salīdzinošo rasu psihiatriju” (1914). Formāli Budula darba vadītājs bija Krēpelīna pēctecis profesors V. Čižs, bet ievaddaḷā H. Buduls pirmām kārtām atsaucas uz Krēpelīna mācību grāmatu.

8. Deviņpadsmitā gadsimta beigās Krēpelīns kritizēja sodu kā vienīgo krimināltiesību sankciju, jo sodīšana nepalīdz ārstēt delinkventas uzvedības cēloņus. Viņš uzsvēra delinkvences psiholoǵisko cēloņu noskaidrošanas nozīmi. Pēc viņa domām, ekskulpācijai (anglu val. exculpate - reabilitēt, attaisnot) bija jābūt atkarīgai no noziedznieka psihiskā stāvokḷa un atbildība par viṇa atbrīvošanu jāpārliek uz psihiatru pleciem. Krēpelīns bija pārliecināts, ka recidīvisms un recidivējoša delinkvence ir cieši saistīta ar psihiskiem traucējumiem, un sekmēja to, lai Sodu likumā tiktu iekḷauts ierobežotas pieskaitāmības jēdziens. ${ }^{142}$

Protams, viņa viedoklim bija arī pretinieki, piemēram, Karls Vilmanss (Karl Wilmanns, 1873-1945), Heidelbergas psihopatoloǵijas skolas dibinātājs, ${ }^{143}$ kurš darbu Heidelbergas klīnikā uzsāka kā Krēpelīna asistents

140 Fedor Sluchevskii, Psikhiatriia (Moskva: Medgiz, 1957), 29.

141 Isidorus Brennsohn, Die Aerzte Livlands von den ältesten Zeiten bis zur Gegenwart, 375.

142 Hans Joachim Salize, Harald Dreßing, Placement and Treatment of Mentally Ill Offenders - Legislation and Practice in EU Member States (Mannheim: Central Institute of Mental Health, 2005), 17.

143 Mundt, C. H. Hoffmann, Wilmanns, J. "Karl Wilmanns' theoretical contributions and his clinical practice. What does it mean for contemporary psychiatry?" Der Nervenarzt 82 (1): 79-89. 
un daudz pētīja klaidoņu psihopatolog̣iju. ${ }^{144}$ Viņš uzskatīja, ka juridiskāa prakse kḷūs neparedzama un netaisnīga, ja starp pieskaitāmību (tātad piln̄̄gu tiesisku atbildību) un nepieskaitāmību parādīsies starpstāvoklis ierobežota pieskaitāmība. ${ }^{145}$ Mūsdienās ierobežotas pieskaitāmības institūts pastāv vairākās pasaules valstīs.

\section{Secinājumi}

Raksturojot situāciju stacionārās psihiatriskās palīdzības jomā Baltijas guberņās profesora E. Krēpelīna laikā, jāsecina, ka to veidoja lielas ārstniecības un aprūpes iestādes, klīnikas (arī ar akadēmisku funkciju), mazas nodaļas somatisko slimnīcu paspārnē, patversmes; pēc pamatfinansējuma avota tās var iedalīt privātajās, pilsētu finansētajās un valsts psihiatriskajās iestādēs; sākās psihiatrijas decentralizācija un deinstitucionalizācija, kḷuva pieejama ǵimenes aprūpe un speciālās pedagoǵijas elementi.

Vairums psihiatrisko iestāžu pacientu bija vīrieši - līdzīgi kā citur Krievijā un pretēji Eiropas valstīs novērotajam.

Līdzīgi kā mūsdienās, tā laika psihiatrijai bija divi galvenie izaicinājumi - sniegt neatliekamu palīdzību akūtiem (bieži vien sabiedriski bīstamiem) slimniekiem un nodrošināt ilgstošu aprūpi hroniski slimajiem. Analizējamā laikposmā neviens no šiem jautājumiem netika pilnvērtīgi atrisināts. Reg̣iona centrālās pilsētas Rīgas valsts psihiatriskais stacionārs - psihiatriskā nodaḷa Dievam tīkamās iestādēs Aleksandra Augstumos - uzṇēma hroniskus slimniekus no visa reg̣iona, taču bija konceptuāli novecojusi.

Reǵiona galvenās specializētās ārstniecības iestādes - Dorpatas Universitātes Nervu un psihisko slimību klīnikas - vadītājs Krēpelīns (iespējams - arī iepriekšējais tās vadītājs H. Eminghauss) bija tikai viesstrādnieks, kuru vairāk interesēja eksperimentālā medicīna, farmakoloǵija un pasniedzēja darbs. Praktiskajā darbā viņam trūka pieredzes un bija lielas grūtības komunikācijā ar pacientiem, turklāt viņam bija problēmas pielāgoties valsts noteikumiem. Taču tas, protams, nemazina viṇa

${ }^{144}$ Erwin Straus, "The life and work of Karl Wilmanns," The American Journal of Psychiatry 102 (5): 688-691.

${ }^{145}$ Hans Joachim Salize, Harald Dreßing, Placement and Treatment of Mentally Ill Offenders - Legislation and Practice in EU Member States (Mannheim: Central Institute of Mental Health, 2005), 17. 
ieguldījumu Baltijas psihiatrijas attīstībā - jauno ārstu skološanā. Darbs multikulturālā vidē, iespējams, lika pamatus Krēpelīna idejām par transkulturālu psihiatriju.

\section{State of Psychiatry in the Baltic Governorates of the Russian Empire in the Late Nineteenth Century: Role of Emil Kraepelin (1856-1926)}

There has been a major progress in psychiatry since about the midnineteenth century onwards - drawing on the experience and knowledge gained on prevalence and natural course of mental diseases; mental institutions of a new format (pavilion type hospital or hôpital pavillonnaire) were built; "non-restraint" and "open door" systems, family care model and work therapy were implicated. As a result, the outcomes of treatment have improved: mortality reduced, and remission rates increased. Because of the overcrowding of the large hospitals, the deinstitucionalisation and the decentralisation of mental health services were started. In the Baltic governorates of the Russian Empire the inpatient care of mental disorders was provided in diverse settings: in the psychiatric hospitals and clinics, special wards of general hospitals, in the asylums and so-called "temporary unit" (Zwischenstation) in Riga. The services were state-owned, selfgoverning bodies-owned and the private ones. The Dorpat/Yuryev (now Tartu) University Clinic of Neurology and Mental Diseases was the innovative and leading psychiatry institution in the region, that implemented the adacemic function as well.

The Dorpat/Yuryev (now Tartu) University Clinic of Neurology and Mental Diseases was the innovative and leading psychiatry institution in the region. The oldest and the largest mental institution in the Baltic governorates - Riga Alexander Heights mental hospital - was the outmoded (corridor plan) institution. When the later famous german psychiatrist Emil Kraepelin (1856-1926) became the director of the Dorpat/Yuryev clinic (1886-1891), he referred uncurable patients and seniors needing care to the Alexander Heights mental hospital. Both mental institutions were overcrowded; the issue of care for chronically mentally ill and disabled persons 
was unresolved, as was the urgent task of emergency psychiatric inpatient placement for acutely mentally ill.

Regardless the brevity that E. Kraepelin was the head of the Clinic and the visiting full profesor of psychiatry in Dorpat/Yuryev University, he had a great influence on later psychiatrists of Latvia. The multicultural experience in Dorpat might have become the basis for Kraepelin's ideas of transcultural psychiatry.

Keywords: Emil Kraepelin, University of Dorpat, psychiatry, Baltic governorates of the Russian Empire, Riga Alexander Heights mental hospital, the late $19^{\text {th }}$ century, social welfare, special pedagogy.

\section{Vladimirs Kuznecovs}

Dr. med., Latvijas Universitātes Medicīnas fakultāte /

University of Latvia, Faculty of Medicine

\section{Marina Loseviča}

psihiatre, lektore, Latvijas Universitātes Medicīnas fakultāte /

psychiatrist, lecturer, University of Latvia, Faculty of Medicine 